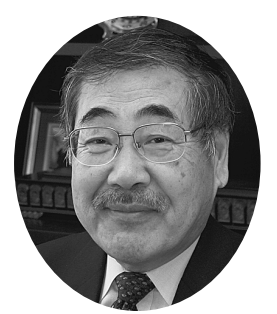

小島 陽*

Journal of Japan Institute of Light Metals, Vol. 58, No. 10 (2008), pp. 526-548

\title{
Platform science and technology for advanced magnesium alloys
}

\author{
Yo KOJIMA*
}

Keywords: magnesium alloy, diecasting alloy, wrought alloy, recrystallization, tensile property, heat resistance, recycle

\section{1.はじめに}

著者は東京工業大学からアルミニウムおよびマグネシウム 合金の時効析出に関する研究を始め, 長岡技術科学大学に転 任後, 鋳造用および展伸用マグネシウム合金の時効析出に加 えて，合金開発，製造プロセス，リサイクル等の実用化に向 けた研究にも着手し, 現在に至っている。その間, 文部科学 省科学研究費の特定領域研究「高性能マグネシウムの新展開 - 21 世紀の超軽量金属材料一」の領域代表者として, マグ ネシゥムの本性を生かしつつ, 高性能化を進める, 学術的観 点からの研究も進めてきた。今回, これらの業績も含めた軽 金属学会への貢献が認められ, 軽金属学会賞という最高の名 誉ある賞を受賞し, 身に余る光栄と感謝しています。本稿で は，これまでの研究生活の中で転機となった特定領域研究の 内容之, その後, 本学にて進めてきたマグネシウム合金の高 性能化, 実用化に向けた研究の一部について述べることとす る。

\section{2. 特定領域研究}

地球規模での環境負荷低減には, 自動車をはじめとする車 両構造体の軽量化，エネルギーの有効活用を促進する技術開 発が不可欠である。軽量性・高比強度 ・高比剛性・高ダンピ ング性・良好な電磁シールド性などを有するマグネシウムは, ミレニアム環境問題の解決にかかるキー・ママリアルの 1 つ である。高齢化社会のための軽量構造化, 水素エネルギーの 進展, 宇宙空間の広範な利用などの課題に応えるには, マグ ネシウムの特徵を生かしつつ, 低延性・低勒性, 低加工性, 腐食性などを新しい視点から総合的に解決し, 水素吸蔵開始 点の低温化・大容量化などの高度化をはかる革新的技術展開 が求められている。本特定領域研究では, その学術的バック グラウンド（マグネシウム・プラットフォームサイエンス） を確立し, 上記の技術革新を諸現象の合理的な理解の上で実 施していくこととした。具体的には，21 世紀の超軽量金属材 料をキーワードとして，1）組織・構造制御の視点からの新 合金探索と高度構成設計，2）材料効率向上を目指した環境
調和型表面改質とリサイクルプロセスの確立, 3）新しい機 能性合金の探索と新プロセス開発などの研究を多面的に推し 進めてきた。本稿では, 構造材に関して得られた主な研究成 果について述べる。

\section{1 高度構成設計グループ}

本研究班における金属基材料の高度構成設計は, (1)合金構 成設計, (2)微視組織設計, (3)構造体化設計から構成されてい る。具体的な共通研究課題としては, マグネシウムの大きな 問題である低い塑性変形能や破壊勒性, 衝突安全性の向上に 関する研究を共同して行い, その変形挙動の解析, 制御につ いて詳細に検討することを目的とした。本グループでは，ア トムスコピック, ミクロ, メゾ, マクロスケールの各階層で のマルチスケール制御を行うことにより, 多様な特性を同時 に有するトレード・オフ・バランシングされた高性能マグネ シウム合金の創製を検討した。

材料のクリープ変形には様々な変形機構が存在するが, 転 位の $\operatorname{climb}$ (上昇運動) が律速となる变形機構が実用材料で よく見られる。上昇運動律速のクリープでは定常クリープ速 度は材料の積層欠陥エネルギーに依存することが明らかにさ れており, 合金化により積層欠陥エネルギーを低下させるこ とは高温強度の向上に繋がる。そこでマグネシウムの積層欠 陥エネルギーにおける合金化の影響を第一原理計算により調 ベ，マグネシウム合金のクリープ特性におけるマテリアルデ ザインの可能性を調べた。その際, マグネシウムでは支配的 なすべり系は底面すべりであるので, 底面での積層欠陥にの み注目し, 添加する溶質原子としては Y, Ca, Al, Zn, Li とした。 これらは実用マグネシウム合金の代表的な添加元素である。 図 11) に示すように, $\mathrm{Al}, \mathrm{Ca}, \mathrm{Y}$ の添加はマグネシウム合金の 積層欠陷エネルギーを低下させる。特にY の添加による積層 欠陥エネルギーの低下は顕著であり, クリープ特性の向上が 期待できる。過去の実験結果でも Y はクリープ特性を向上さ せることが報告されており ${ }^{2)}$, 計算結果とも一致している。 今後合金探索の範囲を広げれば，新しい高クリープマグネシ ウム合金のマテリアルデザインも可能である。

一方では，多結晶マグネシウム合金の変形機構解析から，

*長岡技術科学大学 学長（＝ 940-2188 新潟県長岡市上富岡市 1603-1)。 Nagaoka University of Technology (Kamitomioka-machi 1603-1, Nagaoka, Niigata 940-2188).E-mail: kojima@jcom.nagaokaut.ac.jp 受付日: 平成 20 年 8 月 22 日 受理日: 平成 20 年 9 月 15 日 
特に粒径が $10 \mu \mathrm{m}$ 以下の微細粒多結晶合金においては，図 2 に示すように, 従来から知られている室温における变形機構 をくつがえす新たな発見，（1）非底面転位が活発に活動する こと，(2）全变形量の $8 \%$ 以上もの粒界すべりが生じること, （3）動的回復が生じ, 双晶変形がその役割を担っているこ

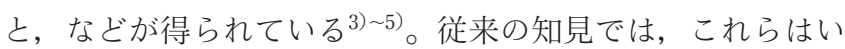
ずれも高温で生じる機構であると思われており, 室温で観察 されたことは非常に意義が大きい。このことは，微細粒を有 する合金では結晶配向制御により室温加工性の向上の可能性 を示唆している。

さらに, 図 3 に示すように, RS P/M 法で作製した $\mathrm{Mg}_{97} \mathrm{Y}_{2} \mathrm{Zn}_{1}$ 合金において新たな $14 \mathrm{H}$ 長周期規則構造が出現す ること，それに加えてナノ微細組織が形成され，その結果， 世界最高レベルの耐力 $610 \mathrm{MPa}$ ，伸び $5 \%$ と超高強度かつ延 性のある合金の開発にも成功している ${ }^{6)}$ ９）。その比強度

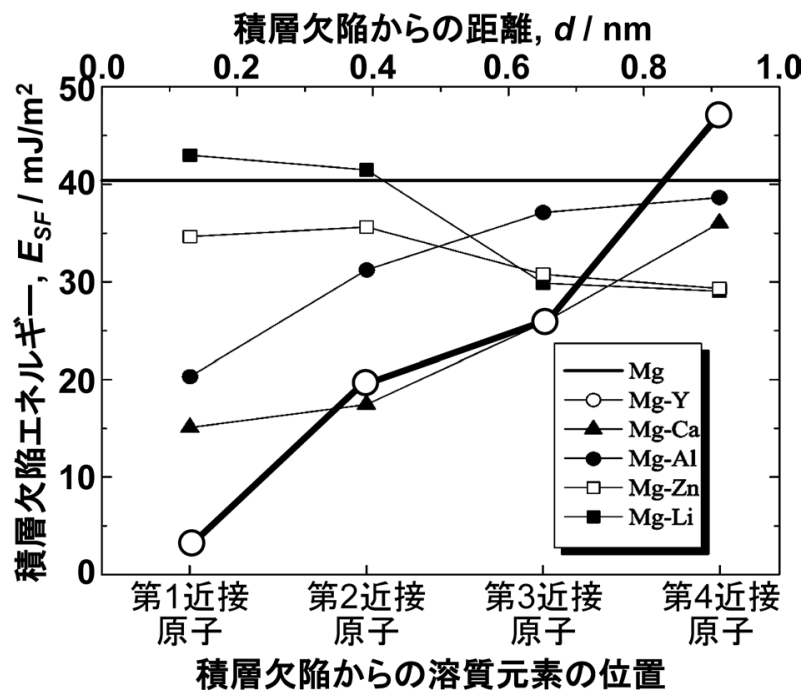

図 1 マグネシウム合金の積層欠陥エネルギーと溶質元 素の偏析サイトの関係 $\left(\sigma_{0.2} / \rho\right)$ は $326 \mathrm{MPa} / \mathrm{Mg} \cdot \mathrm{m}^{-3}$ である。これは, 商用の鋳造用 マグネシウム合金 $\left(\mathrm{AZ} 91-\mathrm{T} 6,83 \mathrm{MPa} / \mathrm{Mg} \cdot \mathrm{m}^{-3}\right)$ の約 4 倍であ り, 商用チタン合金 $\left(\mathrm{Ti}-6 \mathrm{Al}-4 \mathrm{~V}, 247 \mathrm{MPa} / \mathrm{Mg} \cdot \mathrm{m}^{-3}\right)$ やアルミ ニウム合金（7075-T6, $\left.179 \mathrm{MPa} / \mathrm{Mg} \cdot \mathrm{m}^{-3}\right)$ をむ上回る。本合金 は試験温度 $150^{\circ} \mathrm{C}$ でも $510 \mathrm{MPa}$ という高い降伏強度を示し, $200^{\circ} \mathrm{C}$ 以下では商用の耐熱マグネシウム合金（WE54-T6や TMT-WE43 (Mg-Y-Nd)) の 2 3 倍の高い高温強度を持って

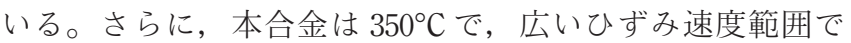
$300 \%$ 以上の伸びを示し, 特に初期ひずみ速度 $2 \times 10^{-1} \mathrm{~s}^{-1}$ に おいて $780 \%$ の最大伸びを示す。ひずみ速度感受性係数（m 值）は 0.4 であり，高速超塑性を示すことが明らかである。 工業的加工速度での超塑性加工が可能であり, 数秒で 1 つの

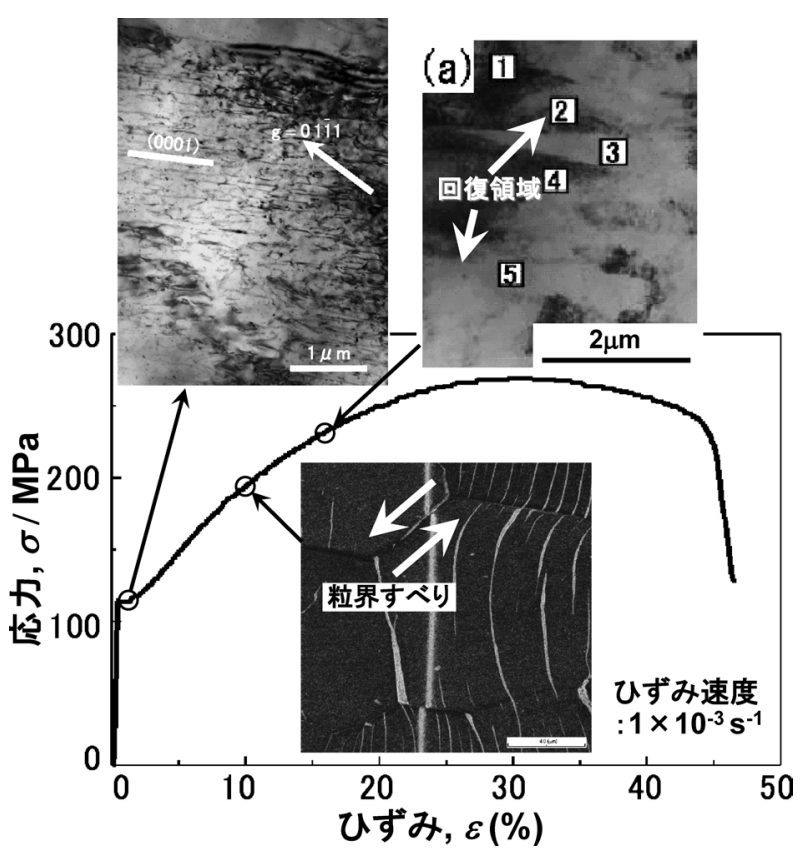

図 $2 \mathrm{ECAE}$ 加工を施し微細粒とした AZ31 マグネシウム 合金の応力ーひずみ曲線と変形に伴う組織变化

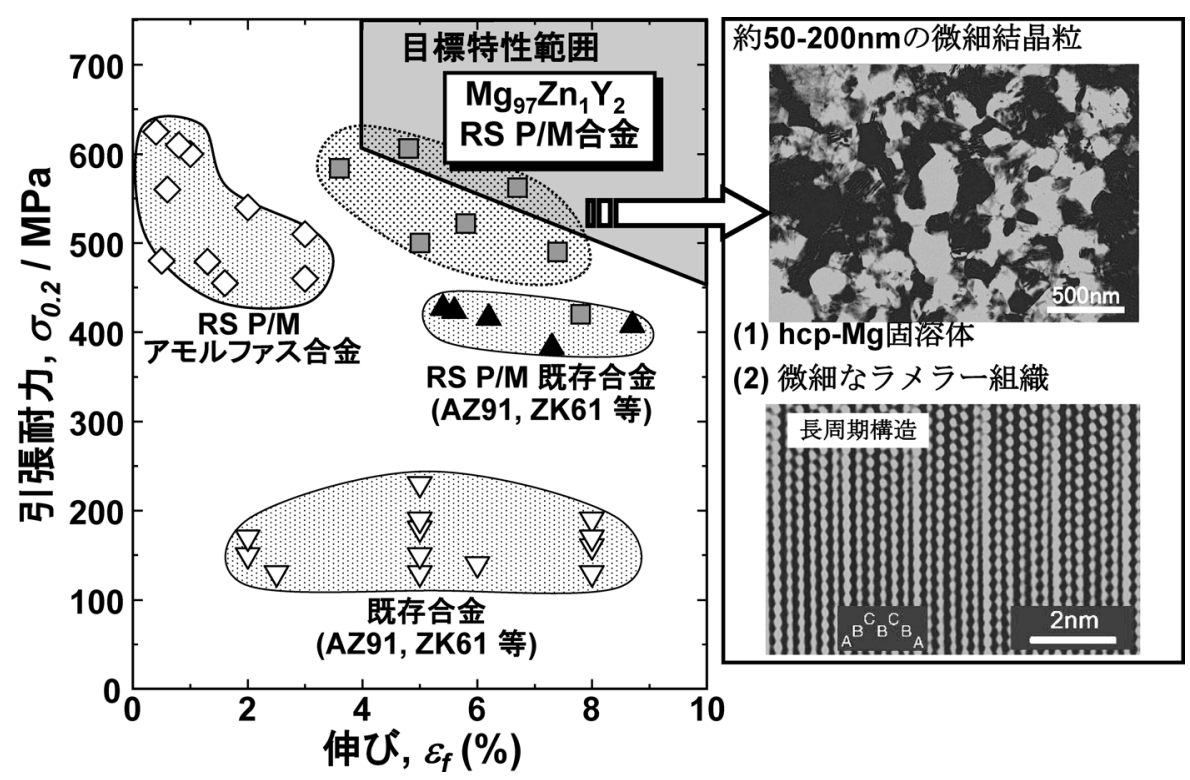

図 $3 \mathrm{RSP} / \mathrm{M}$ 法により作製した $\mathrm{Mg}_{97} \mathrm{Zn}_{1} \mathrm{Y}_{2}(\mathrm{~mol} \%)$ 合金の引張特性と TEM 組織 $\mathrm{RS} P / \mathrm{M}$ ：急冷凝固後，粉末治金法により作製 
製品を製造することができることを意味する。

\section{2 材料効率向上技術グループ}

本研究グループでは，環境に優しい表面改質技術としての クロムを含まない表面機能付与技術とリサイクルを容易にす るための剥離・分離技術の研究開発，さらには高性能な素材 製造のための液相プロセス要素技術に展開可能な材料創製技 術の開発を目的とした。

図 $4^{10)}$ に示すように，マグネシウム合金の耐食性，接着性 などを改良する技術としての 6-ジへキシルアミノ-1,3,5-トリア ジン-2,4-ジチオール（DHN）を用いる有機めっき処理条件の 最適化により生成される被膜は既存のクロメート処理より耐 食性に優れること，電気絶縁性を有することを明らかにする

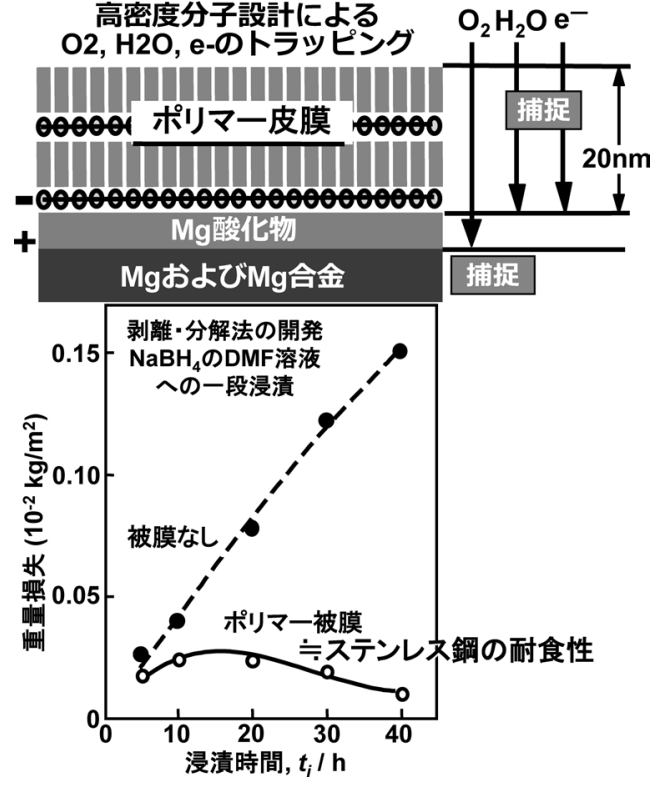

図４トリアジンチオールを用いた高耐食性・易分離ポ リマープレーティング
とともに， $\mathrm{NaBH}_{4}$ の DMF 溶液への一段の浸漬という簡便な 剥離・分解法の開発にも成功している。さらに, DAN 有機 めっき処理した AZ91 マグネシウム合金と EPDM のペルオキ シド架橋下に打ける接着性について検討し，母材破断をする 程度まで強力な接着強度を示す処理条件を見出している ${ }^{11)}$ 。 さらに環境に優しい表面処理法として，他の金属よりマグネ シウムの蒸気圧が高いことを利用し，マグネシウム合金の表 面に高純度マグネシウムを蒸着する方法にも取組んだ。図 5 に示すように, 高純度マグネシウム蒸着膜の成膜条件の最適 化により大面積でも欠陥が少なく, その耐食性は AZ91D 合 金を大きく上回り，6N の高純度マグネシウム合金と同等レ ベルまで向上することを示す12) 14) とともに，図 6 ${ }^{15 ）}$ に示す ように，蒸着被覆を施した AZ31 合金チップ材を温間押出す ることにより，バージン材と同等レベルの特性にまで改善で きることも明らかにしている。さらに，そのチップ材にシリ 力 $\left(\mathrm{SiO}_{2}\right)$ を添加し, 強加工を施す固相リサイクルにより, 組織的には $\mathrm{Mg}_{2} \mathrm{Si}$ および $\mathrm{MgO}$ が分散した複合材となり, 高

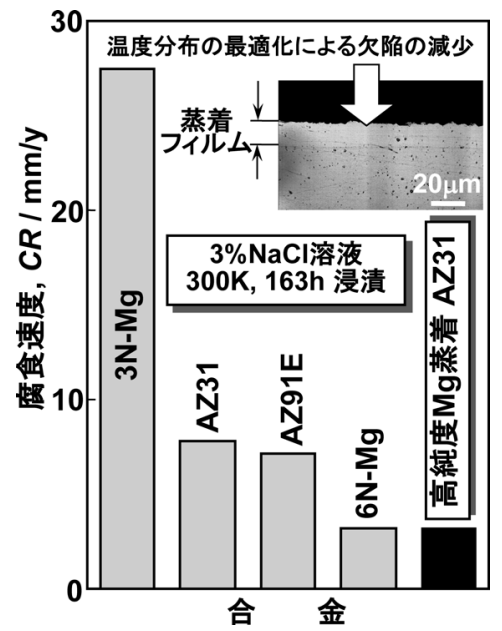

図 5 高純度マグネシウム蒸着による耐食性の改善
固相リサイクルの概念図

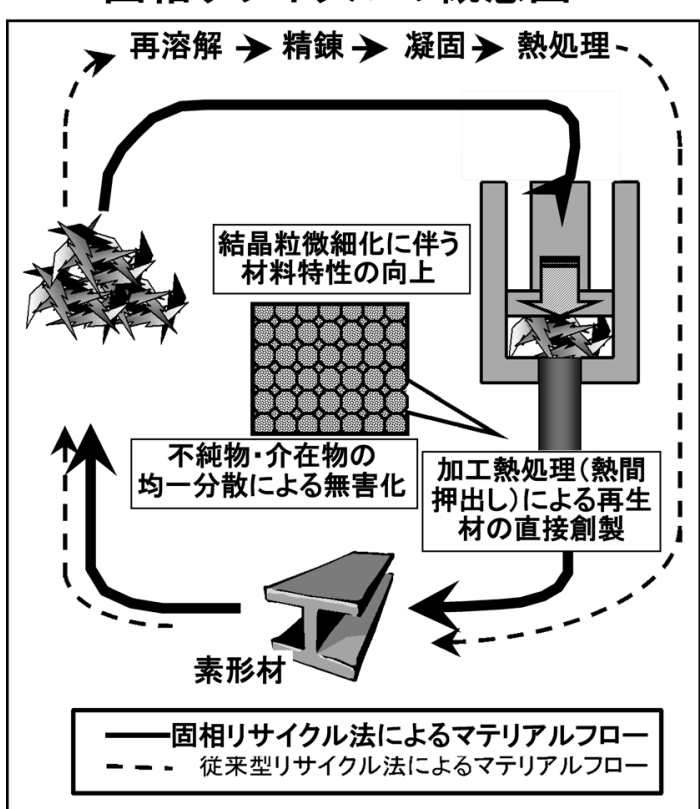

AZ31合金チップ材を用いたリサイクル例

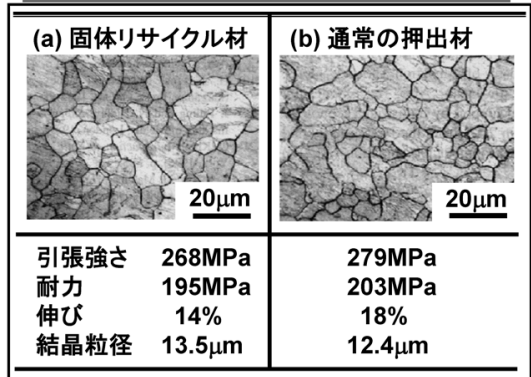

固相合成法考用いたアンシプグレートリサイクル

（廃材としてのシリカ/ガラスの有効利用）

(複合化: $4 \mathrm{Mg}+\mathrm{SiO}_{2} \rightarrow \mathrm{Mg}_{2} \mathrm{Si}+2 \mathrm{MgO}$ )

\begin{tabular}{|c|c|c|c|}
\hline 材料 & $\begin{array}{l}\text { 引張強さ } \\
\text { б/Ma }\end{array}$ & $\begin{array}{c}\text { 耐力 } \\
\sigma_{\mathrm{y}} / \mathrm{MPa}\end{array}$ & $\begin{array}{l}\text { 伸び } \\
\varepsilon(\%)\end{array}$ \\
\hline $\begin{array}{l}\mathrm{H} / \mathrm{E} \text { AZ31-5\%Si } \\
\mathrm{H} / \mathrm{E} \text { AZ31-4\% }\end{array}$ & $\begin{array}{l}375 \\
410\end{array}$ & $\begin{array}{l}306 \\
354\end{array}$ & $\begin{array}{r}12.4 \\
8.2\end{array}$ \\
\hline $\begin{array}{c}\text { H/F AZ31(F) } \\
\text { 4032-Al 合金(T6) } \\
\text { ADC12(F) }\end{array}$ & $\begin{array}{l}260 \\
380 \\
295\end{array}$ & $\begin{array}{l}170 \\
315 \\
185\end{array}$ & $\begin{array}{r}15 \\
9 \\
2\end{array}$ \\
\hline
\end{tabular}

図 6 固相リサイクル法の概念図およびそのチップ材への展開 


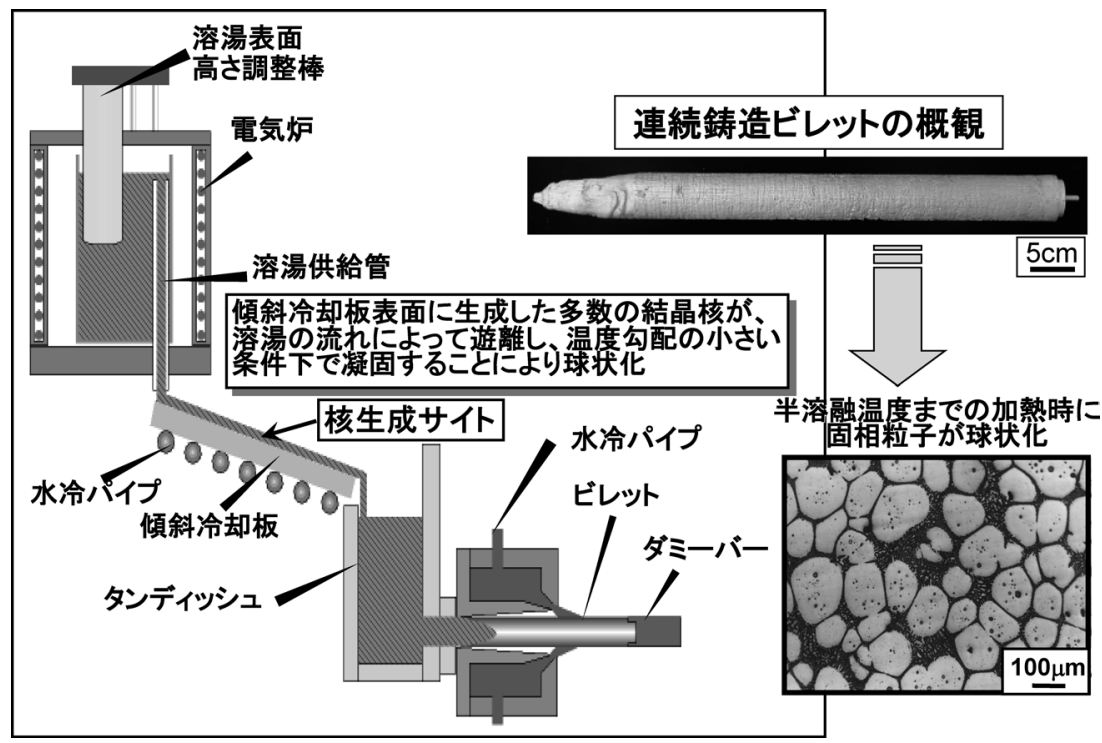

図 7 傾斜冷却板を用いた連続鋳造プロセス

強度化と十分な伸びの維持が可能であることを明らかにして いる16)。

さらに，図７に示すように，冷却端における結晶核の遊離 を促進する傾斜冷却板を活用した凝固組織制御による初晶相 の球状・微細化にも成功し ${ }^{17), 18)}$, 半溶融成形加工用および展 伸用合金の素材製造プロセスとしての連続鋳造技術の確立が 視野に入ってきた。半溶融加工に適した合金として，Zn お よび $\mathrm{Al}$ を多量に添加し, 低温で晶出する化合物量を増やす ことにより, 共晶反応による発熱量が大きくなり, $\mathrm{Zn}+\mathrm{Al}$ 量 が 20 mass $\%$ で $465^{\circ} \mathrm{C}, 15$ mass $\%$ で $535^{\circ} \mathrm{C}$ と, 従来のダイカス 卜法に比べ， $100^{\circ} \mathrm{C}$ 以上低温であ成形が可能であること，た だし，化合物量の増加とともに，化合物が粒界にネットワー クを組むため，流動性および適度な引張特性を得るためには $\mathrm{Zn}+\mathrm{Al}$ 量としては $15 \mathrm{mass} \%$ 以下にする必要があることを明 らかにしている(19),20)。これらの成果は低温・高速プロセスに よる省エネルギー・高効率製造プロセスを可能にする。

一方では，マグネシウムの溶融塩電解精製について検討し， 高純度のマグネシウムを得るための電解条件等を明らかにす るとともに，マグネシウム合金スクラップ中からの Fe の除 去, 高純度化等を含めたリサイクルにも溶融塩電解精製法が 適用可能であることを明らかにした ${ }^{21)}$ 。さらに図 $8^{22)}$ に示す ように, 電析した $\mathrm{Mg}$ 金属中の $\mathrm{La}$ 量は溶融塩の $\mathrm{LaCl}_{3}$ 濃度に ほぼ比例する結果が得られ，また陰極電位については，陰極 過電位が $-0.3 \mathrm{~V} \sim-1.0 \mathrm{~V}$ の範囲でマグネシウム金属中に La が多く含まれる傾向が認められた。溶融塩中の $\mathrm{LaCl}_{3}$ 濃度が $1 \mathrm{~mol} \%$, 陰極過電位 $-0.3 \mathrm{~V}$ のき La を 0.55 mass $\%$ 含むマグ ネシウムを得ることができている。以上のように，希土類金 属を含むマグネシウムを溶融塩電解により直接製造できるこ とを明らかにするとともに，マグネシウムの耐食性が少量の 希土類金属の添加により大幅に向上することも示した。

これらの成果も含め, 特定領域研究全体で 458 編の学術論 文としてまとめられている。また，図 9 に示すように，軽金 属学会におけるマグネシウム合金に関する講演発表む特定領 域研究の始まりとともに急激に活発化し，最近 3 年間は 120 件強にまで達している。その研究内容屯軽金属学会の会員が

\section{溶融塩中への $\mathrm{LaCl}_{3}$ 添加による同時電析}

陽極: $2 \mathrm{Cl}^{-} \rightarrow \mathrm{Cl}_{2}+2 \mathrm{e}^{-}$

陰極: (1) $\mathrm{Mg}^{2+}+2 \mathrm{e}^{-} \rightarrow \mathrm{Mg}$ (2) $\mathrm{La}^{3+}+3 \mathrm{e} \rightarrow \mathrm{La}$

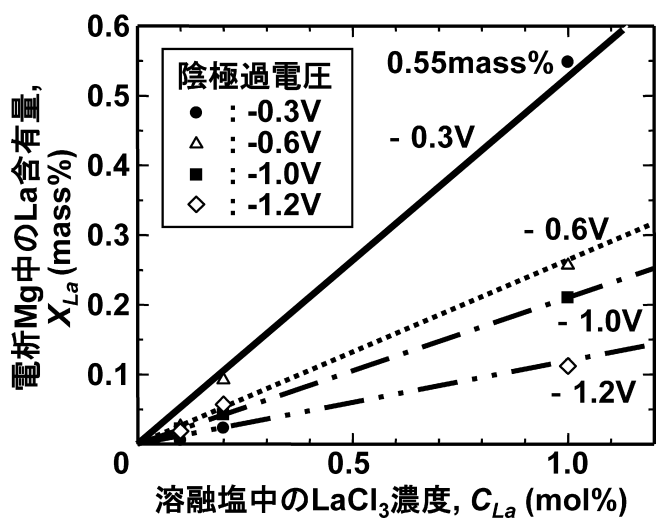

図 8 溶融塩中の $\mathrm{LaCl}_{3}$ 濃度と電析 $\mathrm{Mg}$ 金属中の $\mathrm{La}$ 量の 関係

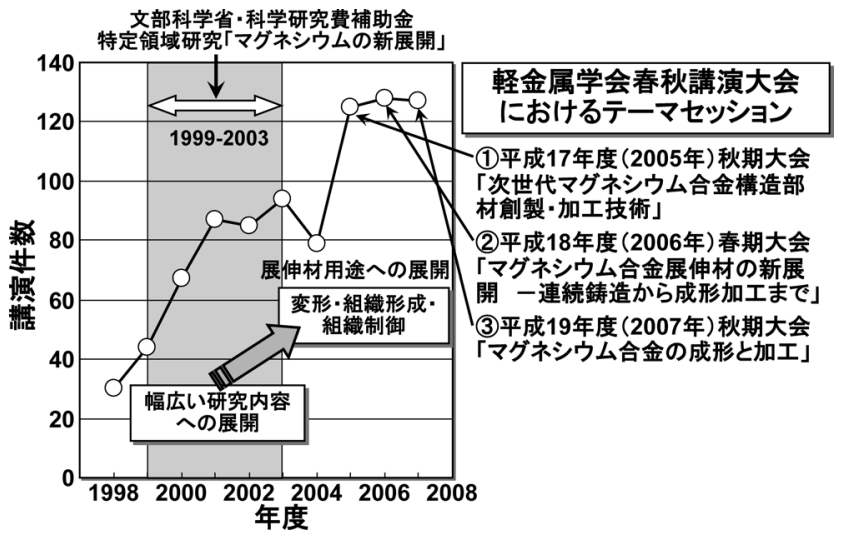

図 9 軽金属学会の春秋講演大会に打けるマグネシウム 合金関係の年間講演件数の推移

得意とする展伸材に関する分野への研究へとシフトしつつあ る。それらの成果をむとに, 若い研究者らが中心となって, 日本金属学会「次世代軽負荷マグネシウム研究会」, 軽金属 
学会「塑性加工によるマグネシウム合金新機能発現部会」, 日本塑性加工学会「軽量化材料研究委員会」, 日本機械学会 「高性能マグネシウム合金の加工技術研究分科会」を立上げ, 応用展開を見据えた学術的研究が進められている。さらに, 本特定領域研究に参画した助教授クラスの先生 6 名が現在教 授に昇進していることからも，特定領域研究が研究者育成の 面でも大いに役立っていること実感している。

\section{3. 高性能化を目指した研究開発}

\section{1 重希土類元素を含む超高強度・耐食・耐熱マグネシ ウム合金の開発}

$\mathrm{Yb}$ を除く重希土類元素は, マグネシウムへの最大固溶限 が大きく，しかも固溶限が温度の低下に伴い急激に減少する という典型的な時効析出型の状態図を示す。そのため, $\mathrm{Mg}-\mathrm{Y}$ 系および $\mathrm{Mg}$ - 重希土類元素系合金の時効析出に関する研究 報告は数多くある。最近では，マグネシウムおよび希土類元 素の産出国であある中国で盛んに研究されるようになってき た。本系合金は航空機，ヘリコプタのギアボックス等への応 用が期待されている。著者らの研究グループ屯 1990 年代か ら重希土類元素を含む合金系の時効析出挙動および機械的性 質を調べ，既存のマグネシウム合金より時効硬化が顕著で， その結果，室温における機械的性質に加えて，耐熱性および 耐食性と屯優れていることを明らかにしてきた ${ }^{23) \sim 40) 。 ま た, ~}$ 前述したように，河村ら ${ }^{6)}$ ９）によって $\mathrm{Mg}-\mathrm{Y}-\mathrm{Zn}$ 系合金の急 冷凝固 + 固化成形材で従来の六方晶金属の $2 \mathrm{H}$ 構造とは異な る $14 \mathrm{H}$ 構造等の長周期構造が出現することが報告され, 急冷 凝固による 50 200 nm の微細結晶粒と長周期構造の出現によ り高強度化が達成されている。そこで，著者らがすでに時効 硬化型高強度合金として開発していた $\mathrm{Mg}-\mathrm{Gd}-\mathrm{Y}-\mathrm{Zr}$ 系合金へ 少量の $\mathrm{Zn}$ を添加し，その組織と引張特性との関係を調べ

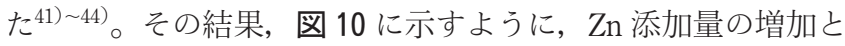
ともに，金型鋳造のように比較的冷却速度の小さい製造プロ セスでも長周期構造を有する化合物が粒界近傍にネットワー クを組むように晶出するようになり，さらに金型中での冷却 時に $0.3 \mathrm{~mol} \%$ 以上の $\mathrm{Zn}$ を含む合金では粒内にも析出するこ とが明らかになった。なお，粒内における析出反応は $415^{\circ} \mathrm{C}$ 付近の比較的高温で生じることから，通常の析出硬化を狙っ

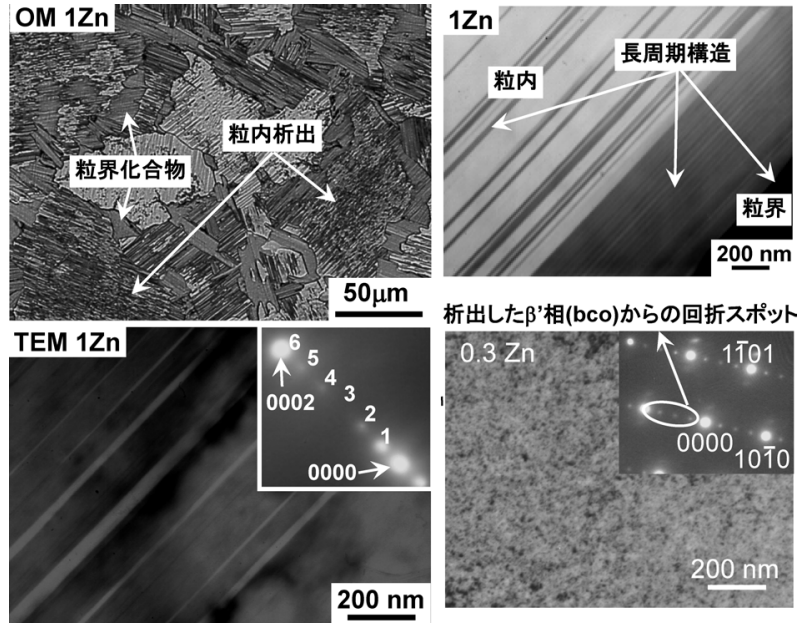

図 $10 \mathrm{Mg}-2.0 \mathrm{Gd}-1.3 \mathrm{Y}-0.3 \sim 1 \mathrm{Zn}-0.2 \mathrm{Zr}(\mathrm{mol} \%)$ 合金鋳造 材および時効材のミクロ組織
た時効処理とは個別に制御可能である。ただし，図 11 の圧 延後溶体化処理を施した試料の引張特性にみられるように, 長周期構造を有する化合物は強度特性よりも，むしろ延性を 向上させることが明らかとなった。引張破面近傍のミクロ組 織を観察すると，既存のマグネシウム合金で観察されるよう な双晶がまったく観察されないことも特徵で, 長周期構造を 有する粒界化合物は延性的な性質を持っていることを示唆し ている。一方で, $Z \mathrm{n}$ 添加量が $1 \mathrm{~mol} \%$ 以下の試料では, 図 12 に示すように, 従来の $\mathrm{Mg}-\mathrm{Gd}-\mathrm{Y}-\mathrm{Zr}$ 系合金と同様に, マグネ シウム固溶体と整合性を有し, $\mathrm{c}$ 軸方向に伸張した楕円形状 の bco 構造の $\beta^{\prime}$ 相の析出により顕著な時効硬化を示す。 $0.75 \mathrm{~mol} \% \mathrm{Zn}$ を含む合金では, $\beta^{\prime}$ 相の析出による時効硬化と 長周期構造を有する粒界化合物の存在により，図 13 のピー

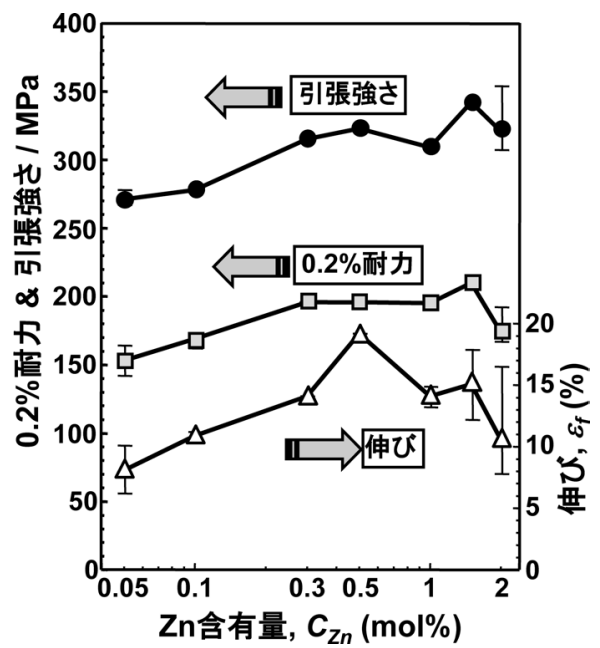

図 11 熱間圧延後溶体化処理した $\mathrm{Mg}-2.0 \mathrm{Gd}-1.3 \mathrm{Y}-$ 0.05 2Zn-0.2Zr (mol\%) 合金圧延材の引張特性
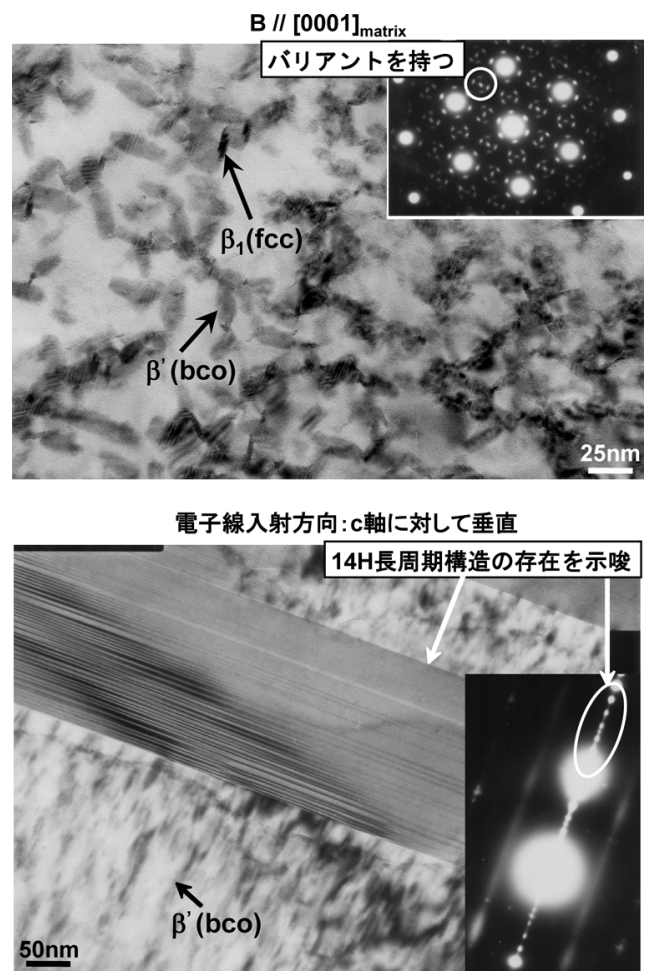

図 $12 \mathrm{Mg}-2 \mathrm{Gd}-1.3 \mathrm{Y}-0.75 \mathrm{Zn}-0.2 \mathrm{Zr}(\mathrm{mol} \%)$ 合金ピーク時 効材の TEM 組織 


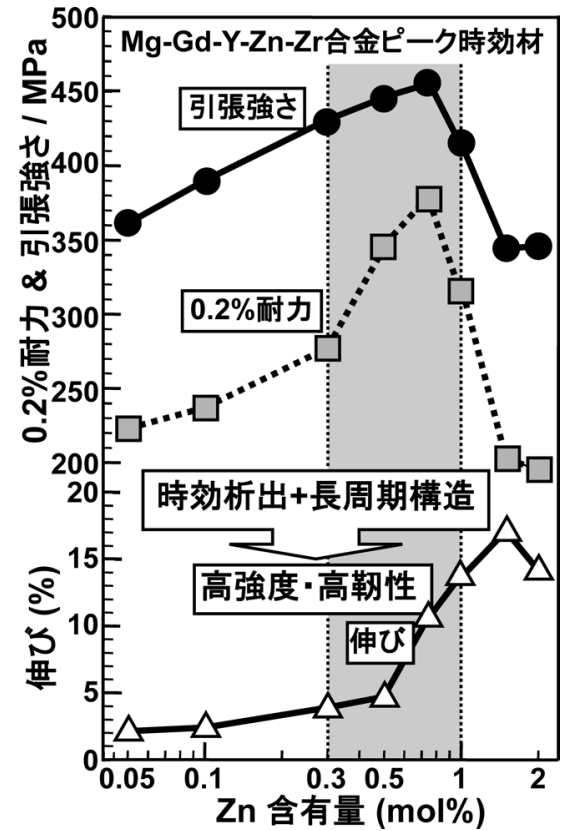

図 13 圧延後 $\mathrm{T} 6$ 処理した $\mathrm{Mg}-2.0 \mathrm{Gd}-1.2 \mathrm{Y}-\mathrm{Zn}-0.2 \mathrm{Zr}$ $(\mathrm{mol} \%)$ 系合金圧延板の引張特性

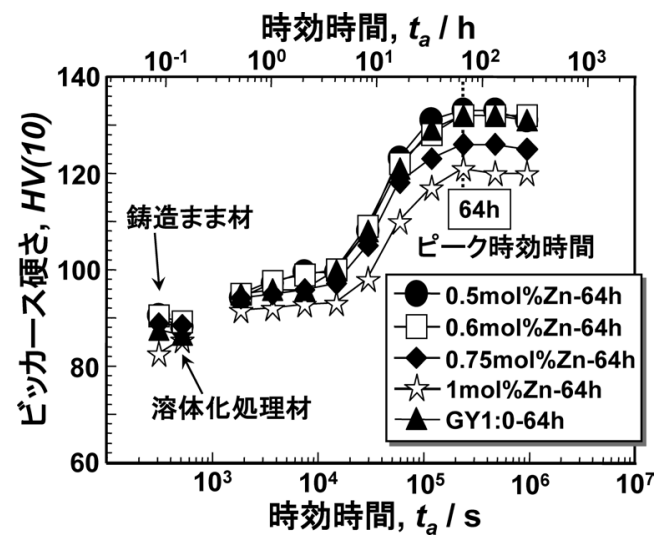

図 $14 \mathrm{Mg}-2.0 \mathrm{Gd}-1.2 \mathrm{Y}-\mathrm{Zn}-0.2 \mathrm{Zr}(\mathrm{mol} \%)$ 合金の $200^{\circ} \mathrm{C}$ に おける時効曲線

ク時効材の引張特性に示すように引張強さ $465 \mathrm{MPa}$, 伸び $10 \%$ と高強度および適度な延性を併せ持つようになる。な お，図 12 に示したように，ピーク時効状態でもすでに $\beta^{\prime}$ 相 の境界には fcc 構造の $\beta_{1}$ 相も析出している。また, 粒界のみ ならず，粒内にも長周期構造を示唆する析出相も底面に平行 に析出する。ただし, Zn 量の増加とともに, 長周期構造を 有する粒界化合物は増加し，伸びが大きくなることから，前 述した溶体化処理材と同様に, T6 処理材でむ, この化合物 は強度特性よりむ, むしろ延性に寄与していると考えられる。

さらに, 熱処理条件と合金組成の最適化による適度な延性 之高強度を有する $\mathrm{Mg}-\mathrm{Gd}-\mathrm{Y}-\mathrm{Zn}-\mathrm{Zr}$ 系鋳造合金開発を目指し, まず溶体化処理として, Mg-2.0Gd-1.2Y-0.5 1.0Zn-0.2Zr （mol\%）合金の溶質元素を最大限まで固溶させるため, 融点 直下まで二段の溶体化処理，すなわち $520^{\circ} \mathrm{C}-8 \mathrm{~h}+525^{\circ} \mathrm{C}-8 \mathrm{~h}$ を施し, その後時効を行った。その結果, 図 14 に示すよう に, ピーク時効硬さは従来の $500^{\circ} \mathrm{C}-24 \mathrm{~h}$ 溶体化処理材より ビッカース硬さ（HV）で 10 15 程度大きくなる。ただし, 各 試料之も硬化に寄与する時効析出物は bco 構造の $\beta^{\prime}$ 準安定

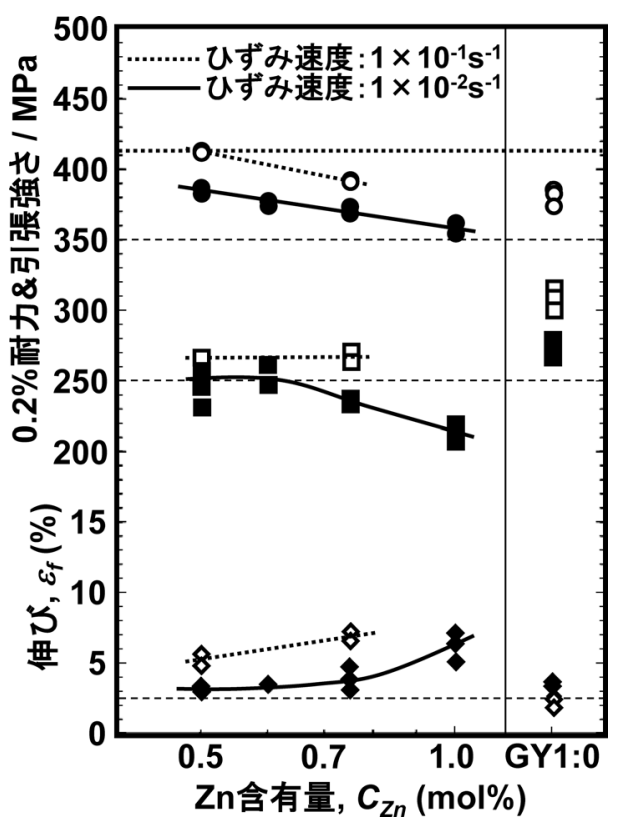

図 15 T6 処理した Mg-2.0Gd-1.2Y-Zn-0.2Zr（mol\%）合 金の引張特性

相で，硬さはその時効析出量に依存する。これらの結果をも とに鋳造材に高温二段溶体化処理後ピーク時効を施した試料 は，図 15 に示すように高強度を示し，ひずみ速度に依存す るものの, $0.5 \mathrm{~mol} \% \mathrm{Zn}$ 添加合金は最大で $413 \mathrm{MPa}$ に達する。

本系合金のような希土類元素を含む合金は溶湯表面に緻密 な酸化膜を形成し, 溶解 - 鋳造時にその酸化膜が溶湯中に混 入する可能性がある。そのため, 航空機部品を製造する場 合, 溶解時に塩化物, ふっ化物を含む精錬用フラックスを用 いて溶湯処理を行う。しかし，Yを含む合金の場合，フラッ クス処理中にY が塩化物, あるいはふっ化物を形成し, 高価 な Y の歩留りが悪くなる。そこで, 鋳造時の酸化膜混入を避 け, 更なる高強度化を目指し, 希土類元素として Gd を単独 添加した Mg-3.2 3.6Gd-0.5Zn-0.2Zr (mol\%) 合金にフラック ス処理を施し, 高温二段溶体化処理後, $225^{\circ} \mathrm{C}$ でピーク時効 を施した ${ }^{45)}$ 。その結果, 図 16 に示すように, 時効温度が高 いにもかかわらず，ピーク時効硬さは HV135 140まで向上 し，図 17 に示すように，各合金ともひずみ速度 $10^{-1} \mathrm{~s}^{-1}$ で $425 \mathrm{MPa}$ 以上の引張強さを示し， $3.6 \mathrm{~mol} \% \mathrm{Gd}$ 添加合金は $430 \mathrm{MPa}$ に達する。なお, 各合金と屯顕著なひずみ速度依存 性を示し，ひずみ速度が大きくなるにつれて強度，伸びとも 向上する。

さらに, $\mathrm{Mg}-\mathrm{Gd}-\mathrm{Zr}$ 合金への $\mathrm{Ag}$ の微量添加により bco 構 造の $\beta^{\prime}$ 相に加えてマトリックス相中に規則 GP ゾーンも形成 され, 時効硬化能が改善されること ${ }^{46)}, \mathrm{Cu}$ と $\mathrm{n}$ の同時添加 により粒界化合物相が延性を有する長周期構造相に変化する ことを明らかにし, その結果, 引張強さ $376 \mathrm{MPa}$ の高強度に 加え，伸び $9.4 \%$ を達成している ${ }^{47)}$ 。

\section{2 ダイカスト用耐熱マグネシウム合金の開発}

地球環境問題から $\mathrm{CO}_{2}$ 排出量の削減と次世代エネルギーへ の対応が迫られている。このような社会的背景から, 実用金 属中最む軽量なマグネシウム合金の自動車部品への応用が期 待されている(8) 50)。その中でも, トランスミッションケー ス，オイルパン，エンジンブロックのように軽量化に有効な 


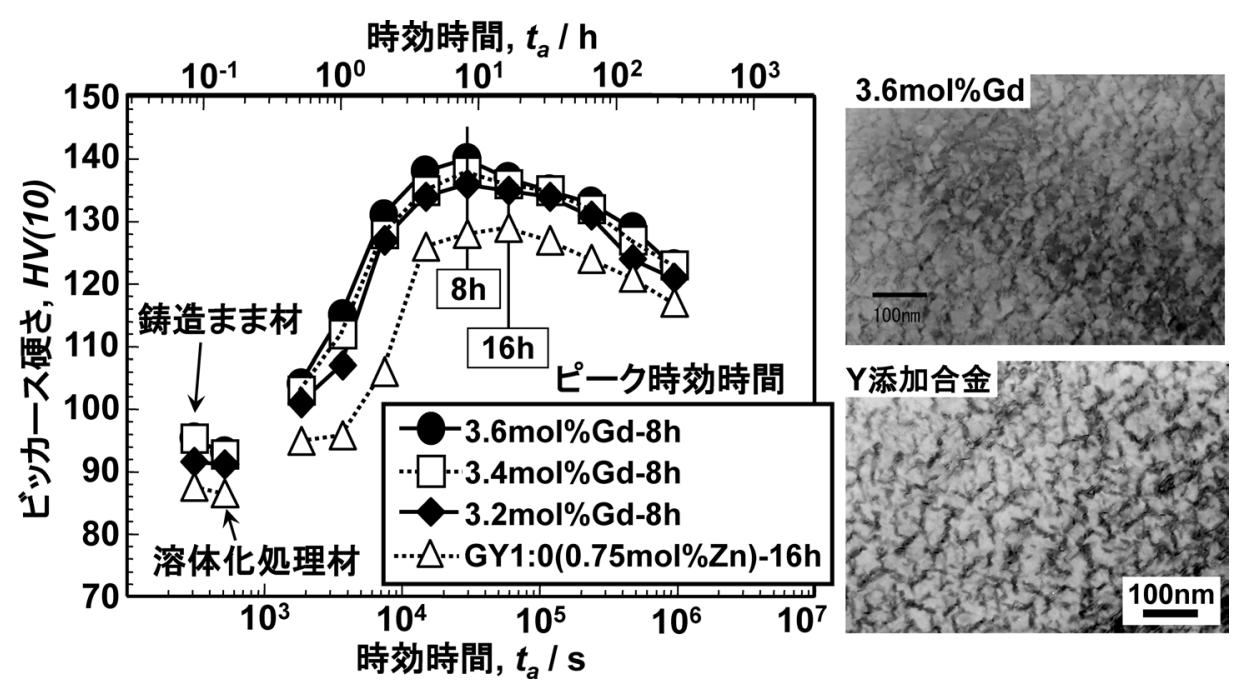

図 $16 \mathrm{Mg}-\mathrm{Gd}-0.5 \mathrm{Zn}-0.2 \mathrm{Zr}(\mathrm{mol} \%)$ 合金の $225^{\circ} \mathrm{C}$ における時効特性と TEM 組織
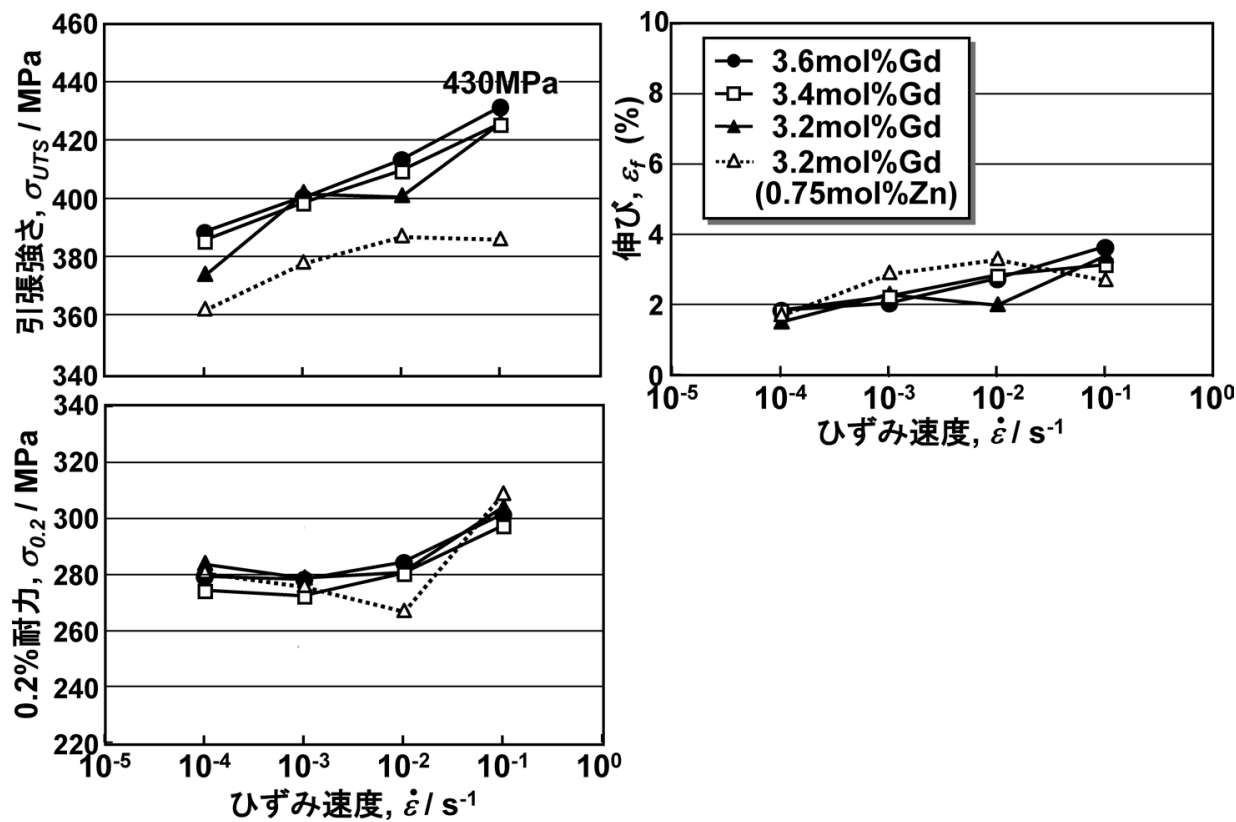

図 $17 \mathrm{Mg}-\mathrm{Gd}-0.5 \mathrm{Zn}-0.2 \mathrm{Zr}(\mathrm{mol} \%)$ 系合金の引張特性のひずみ速度依存性

エンジン周りの部品への応用には耐熱性が要求される。しか しながら，図 18 に示すように，既存のダイカスト用マグネ シウム合金, $\mathrm{Mg}-2 \% \mathrm{Al}-1 \% \mathrm{Si}$ (AS21, 合金組成は以後すべて $\operatorname{mass} \%$ ), $\mathrm{Mg}-4 \% \mathrm{Al}-1 \% \mathrm{Si}(\mathrm{AS} 41), \mathrm{Mg}-4 \% \mathrm{Al}-2 \% \mathrm{RE}$ (RE : 含 有割合がおおよそ $50 \% \mathrm{Ce}-25 \% \mathrm{La}-20 \% \mathrm{Nd}-5 \% \mathrm{Pr}$ の Ce を主体 とした希土類元素）では，現在使用されているダイカスト用 アルミニウム合金（ADC12）より耐熱性の面でかなり劣 る51) 53)。そのため, オートマチック車のトランスミッション ケースの使用温度, 約 $175^{\circ} \mathrm{C}$ でも使用可能な耐熱マグネシウ 么合金の開発が強く要望され, 国内外の材料メーカ, ダイカ ストメーカが耐熱マグネシウム合金開発研究を進めてい る $^{54) \sim 61)}$ 。

著者らも自動車のパワートレイン系部品に適用可能なダイ カスト性および耐熱性に優れるマグネシウム合金の開発を進

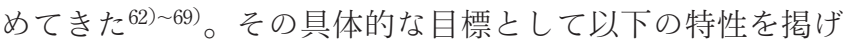
た。

(1) 現在, トランスミッションケースに適用されている
$\mathrm{ADC1} 2$ ダイカスト用アルミニウム合金に匹敵する耐熱性

（2）既存のダイカスト用マグネシウム合金である $\mathrm{Mg}$ 9\%Al-1\%Zn (AZ91D) 合金並みのダイカスト性

本節では，これまで国内外で検討されている耐熱マグネシ ウム合金の種類と, 著者らが進めてきた研究成果について述 ベる。

3.2 .1 国内外で検討されている耐熱マグネシウム合金

表 170) 72) にこれまでに国内外で開発された代表的なダイ カスト用耐熱マグネシウム合金の組成を示す。AS21X 合金は AS21 合金をべースとして RE を少量加えた合金で, ベース合 金よりクリープ特性は改善されているものの, ダイカスト性 は必ずしも改善されていない。耐熱性向上のため, $\mathrm{Mg}$ $5 \% \mathrm{Al}-0.3 \% \mathrm{Mn}$ (AM50) 合金をべース合金として, Sr 大量 に添加した AJ52 合金は $150 \sim 175^{\circ} \mathrm{C}$ の温度範囲におけるク リープ特性は良好であるが，ダイカスト性を維持するために は，溶湯温度 $720^{\circ} \mathrm{C}$, 金型温度 $300 \sim 350^{\circ} \mathrm{C}$ まで上げる必要が ある。また, Sr 含む母合金が高価であるという問題点ああ 
表 1 最近開発された耐熱マグネシウム合金の組成（mass\%)

\begin{tabular}{l|c|c|c|c|c|c|c}
\hline \hline 合金名 & $\mathrm{Al}$ & $\mathrm{Zn}$ & $\mathrm{Mn}$ & $\mathrm{Si}$ & $\mathrm{Ca}$ & $\mathrm{RE}$ & $\mathrm{Sr}$ \\
\hline AS21X & $1.9-2.5$ & - & $0.05-0.08$ & $0.7-1.2$ & - & $0.06-0.25$ & - \\
AJ52 & 4.53 & 0.018 & 0.27 & 0.010 & - & - & 1.75 \\
N & 4.55 & 0.001 & 0.25 & $<0.010$ & 0.19 & - & 0.53 \\
MRI-153 & $4.5-10$ & - & $0.15-1.0$ & - & $0.5-1.2$ & $0.05-1.0$ & $0.01-0.2$ \\
ACM522 & 5.3 & - & 0.17 & - & 2.0 & 2.6 & - \\
\hline
\end{tabular}

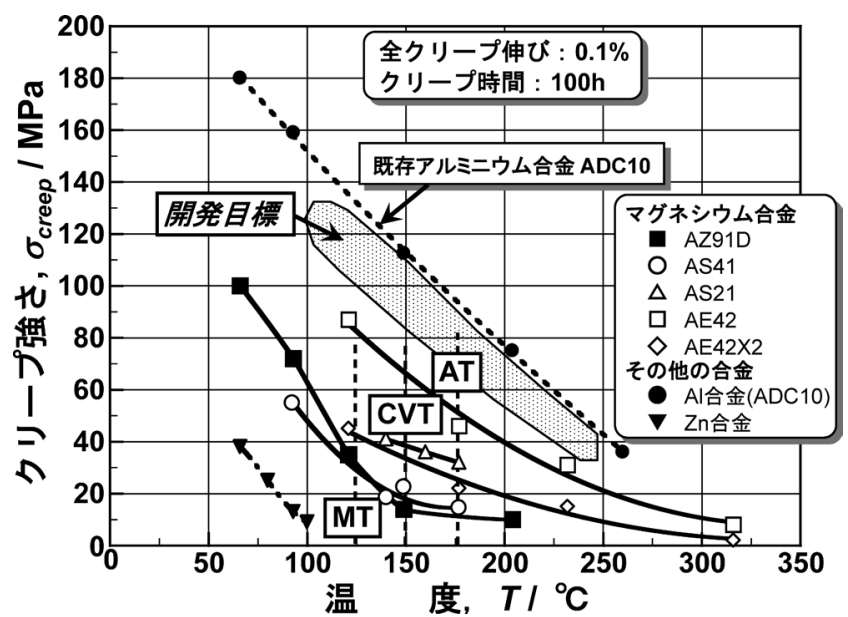

図 18 各種マグネシウム合金のクリープ強さの温度依存 性（MT：マニュアルトランスミッション, CVT：ベルト式トランスミッション, AT：オー トマチックトランスミッション)

る。AJ52 合金の Sr を少なくし，その代替元素として Ca を少 量添加した $\mathrm{N}$ 合金でも AJ52 合金と同様にダイカスト性に問 題点を抱えている。そのため，アルミニウムを 6 mass $\%$ まで 増やし，耐熱性を維持しつつ，鋳造性を改善した AJ62 合金 が開発され，その合金を用いてアルミニウム合金とのハイブ リッド構造にしたエンジンブロックが実用化されている。 MRI-153 合金については特許に記されている組成範囲しか明 らかにされていないが，この合金もクリープ特性は大幅に改 善され，比較的良好なダイカスト性と相まって，現在一部の 車種のトランスミッションケースに搭載されている。ACM522 合金は $\mathrm{Ca}$ 打よび $\mathrm{RE}$ を添加し，耐熱性を向上させた合金で， すでにオイルパンに搭載されている。いずれの合金も $\mathrm{Ca}, \mathrm{RE}$, $\mathrm{Sr}$ 等を添加し, $\mathrm{Al}-\mathrm{Mg}-\mathrm{Ca}$ 系, $\mathrm{Al}-\mathrm{RE}$ 系あるいは $\mathrm{Al}-\mathrm{Sr}$ 系化 合物を粒界近傍に晶出させ, 耐熱性, 特にクリープ特性を向 上させている。最近では, $\mathrm{Al}$ と $\mathrm{Ca}$ のみを添加した $\mathrm{Mg}-5$ $6 \% \mathrm{Al}-2 \sim 3 \% \mathrm{Ca}$ 合金であ，粒界を被覆する $(\mathrm{Mg}, \mathrm{Al})_{2} \mathrm{Ca}$ ある いは $\mathrm{Al}_{2} \mathrm{Ca}$ 化合物の存在により, $200^{\circ} \mathrm{C}$ までの耐熱性を確保 できること，そのクリープ特性は化合物の粒界被覆率に依存 することも明らかにされている73)。

しかしながら，粒界に沿って大量の化合物を晶出させた場 合，ダイカスト時に熱間割れを生じやすくなる。既存のダイ カスト用アルミニウム合金製トランスミッションケースでは, 軽量化之剛性を同時に満足させるため, リブ構造を多数取入 れた薄肉複雑形状となっている。マグネシウム合金はアルミ ニウム合金より更にヤング率が低いため，軽量化を達成する ためには，図19に示すような薄肉複雑形状が必須となる。そ

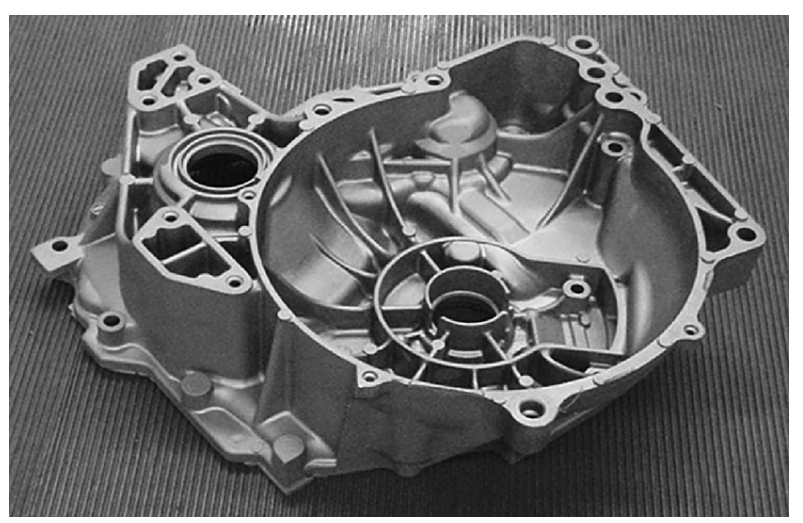

図 19 開発合金を用いたダイカスト試作例：トランス ミッションケース

のような形状まで歩留りよくダイカストするためには, 鋳造 性（流動性, 而熱間割れ性, 耐焼付き性等）屯満足させる必 要がある。そのためには, 上述したような粒界近傍に晶出す る化合物の量と晶出形態を制御することが重要なポイントと なる。

\section{2 .2 耐熱性の改善}

（1）ミッシュメタルから La 単独添加によるミクロ組織変 化

著者らは, 自動車向けトランスミッションケース用マグネ シウム合金として，耐熱性と耐熱間割れ性を兼敉備えた合 金, $\mathrm{Mg}-0.5 \% \mathrm{Zn}-6 \% \mathrm{Al}-1 \% \mathrm{Ca}-3 \% \mathrm{RE}$ (ZAXE05613) 合金を開

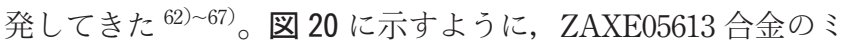
クロ組織中には, 針状および粒状の Al-RE 化合物および最終 凝固部となる粒界に沿って $\mathrm{Al}_{2} \mathrm{Ca}$ 化合物が晶出する。 Powell らは Al-RE 系化合物として $\mathrm{Al}_{2} \mathrm{RE}$ および $\mathrm{Al}_{11} \mathrm{RE}_{3}$ が晶出し, 前者の化合物は粒状で $\mathrm{Nd}$ が濃化し, 後者の化合物は針状で, La が濃化することを報告している74)。クリープ特性の改善を 考えた場合, 化合物は粒界に沿って, あるいは交差するよう に針状に晶出した方が好ましいと考えられる。そこで, ZAXE05613 合金試料中の晶出化合物の EPMA 定量分析を 行った。その結果を図 21 に示す。彼らの結果と同様に, 針 状の $\mathrm{Al}_{11} \mathrm{RE}_{3}$ 化合物には $\mathrm{La}$ が多く含まれ, 粒状の $\mathrm{Al}_{2} \mathrm{RE}$ 化合 物には Ce および $\mathrm{Nd}$ が多く含まれる。そこで, $\mathrm{RE}$ としての 希土類元素の混合物であるミッシュメタル（MM）に代えて $\mathrm{La}$ 単独で添加した $\mathrm{Mg}-0.5 \% \mathrm{Zn}-6 \% \mathrm{~A} 1-1 \% \mathrm{Ca}-3 \% \mathrm{La}$ （ZAXLa05613）合金ダイカスト材を作製し，耐熱性の評価・ 検討を行った ${ }^{68)}$ 。

図 22 に示すように，ZAXE05613 合金およびZAXLa05613 合金のダイカスト材ともに粒界に沿って $\mathrm{Al}_{2} \mathrm{Ca}$ が晶出し，ま た, REを MM から La 単独添加することにより, アスペクト 

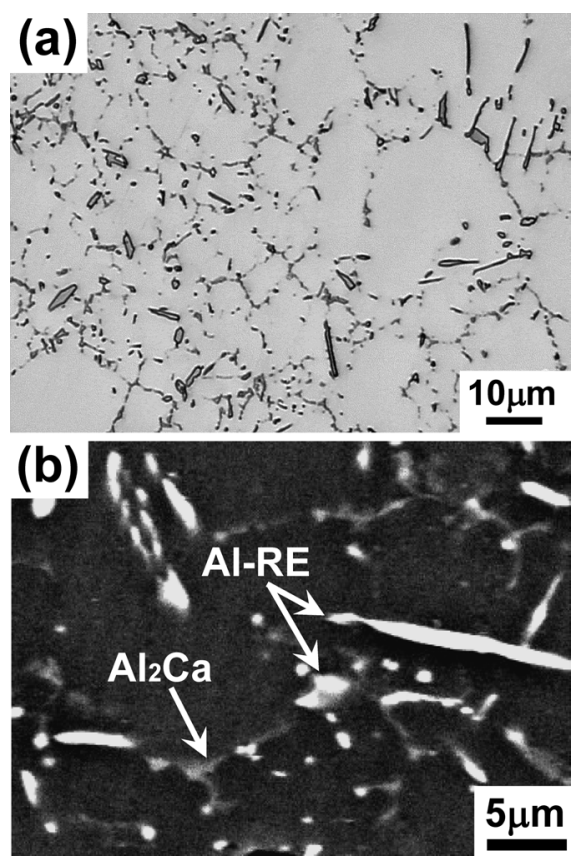

図 $20 \mathrm{Mg}-0.5 \mathrm{Zn}-6 \mathrm{Al}-1 \mathrm{Ca}-3 \mathrm{RE}$ (mass \%, ZAXE05613) 合 金ダイカスト材の（a）光学顕微鏡組織および (b) SEM 写真
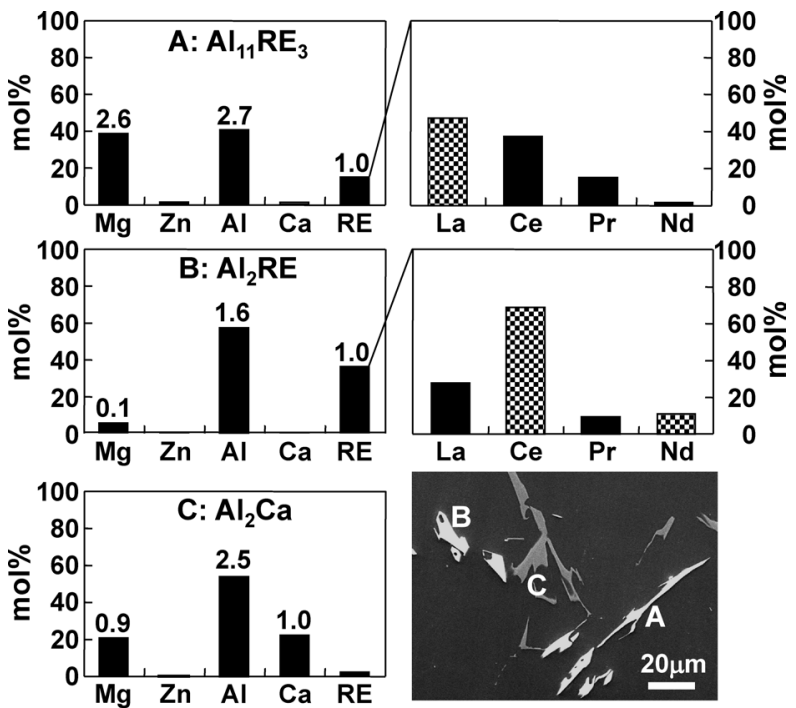

図 21 DSC 測定後の ZAXE05613 合金試料の SEM 写真 およびEPMA 定量分析結果

比の大きな $\mathrm{Al}-\mathrm{La}$ 針状化合物が増加する。さらに，これらの $\mathrm{Mg}-\mathrm{RE}$ 化合物の面積率を画像処理により測定した結果, 6.8\% から 8.1\% と増加していることがわかった。このことは, 2 種類の $\mathrm{Mg}-\mathrm{RE}$ 化合物の化学量論組成からわかるように, $\mathrm{Al}_{11} \mathrm{La}_{3}$ 化合物の方が同じ量の希土類元素量であ化合物を形成 するに足りるアルミニウムを含有すれば，体積率は多くなる ためである。

（2）耐熱性

図 23 に本検討合金の試験温度 $175^{\circ} \mathrm{C}$, 引張負荷応力 $50 \mathrm{MPa}$ におけるクリープ曲線を示す。比較材として AZ91D, AS21, AE42 既存マグネシウム合金および ADC12 アルミニウ ム合金の測定結果も併記した。本検討合金は，既存のダイカ
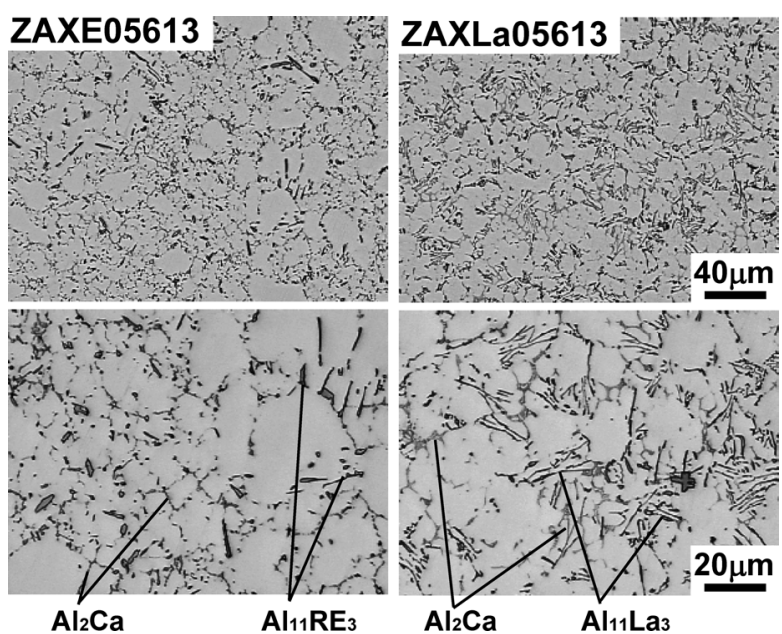

図 22 ZAXE05613 合金および希土類元素として La を単 独添加した $\mathrm{Mg}-0.5 \mathrm{Zn}-6 \mathrm{Al}-1 \mathrm{Ca}-3 \mathrm{La}$ ( $\operatorname{mass} \%$, ZAXLa05613）合金ダイカスト材のミクロ組織

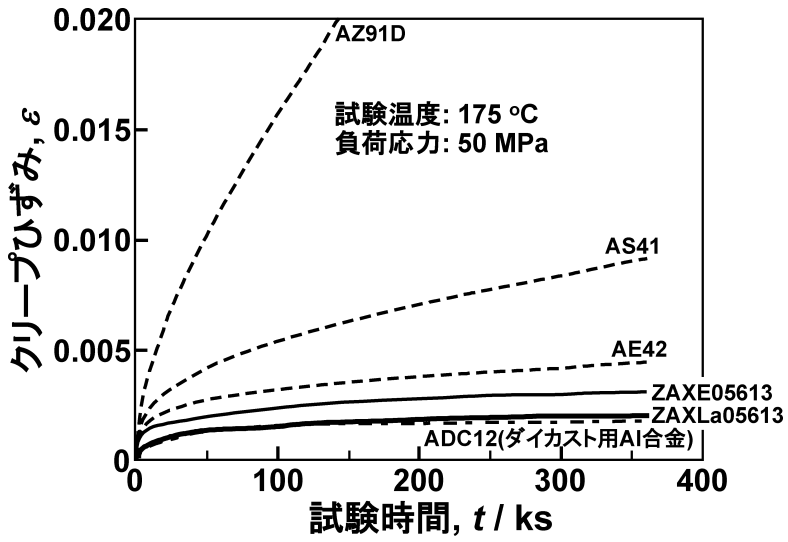

図 23 ZAXLa05613 合金ダイカスト材のクリープ曲線

スト用マグネシウム合金より，初期伸びが小さく，クリープ ひずみも大幅に小さくなる。また， La 単独添加の ZAXLa05613 合金は，ZAXE05613 合金よりもさらに耐熱性が 改善され，パワートレイン系部品としてすでに使用されてい る $\mathrm{ADC} 12$ アルミニウム合金に匹敵するクリープ特性を示す。 図 24 にZAXLa05613 合金のクリープ試験前後の SEM 像お よび TEM 像を示す。既存耐熱マグネシウム合金の AE42 合 金では, $150^{\circ} \mathrm{C}$ 以上の温度条件でクリープ試験を行った場合, 針状の $\mathrm{Al}_{11} \mathrm{RE}_{3}$ 化合物が粒状あるいは塊状の $\mathrm{Al}_{2} \mathrm{RE}$ に分解し, かつ化合物中から排出される余剩な $\mathrm{Al}$ は $\mathrm{Mg}_{17} \mathrm{Al}_{12}$ を形成し, その結果, クリープ特性の劣化を招くことが報告されてい る ${ }^{75)}$ 。今回開発した ZAXLa05613 合金では, クリープ試験前 後で，化合物の形態变化はまったく見られず，針状形態を維 持している。このことは, MM から La 単独添加にすること により, 本実験条件の範囲内では $\mathrm{Al}_{11} \mathrm{La}_{3}$ 化合物が熱的に安 定に存在し得るようになることを示唆している。また, $1200 \mathrm{~h}$ のクリープ試験後でも化合物の周囲には多数の転位が観察さ れることから, 熱的に安定で, 粒界に晶出する $\mathrm{Al}_{2} \mathrm{Ca}$ および 粒界を横切る $\mathrm{Al}_{11} \mathrm{La}_{3}$ 化合物が転位のピン止めの役割を充分 に果たし，クリープ変形を抑制しているものと考えられる。 なお， $175^{\circ} \mathrm{C}, 65 \mathrm{MPa}$ 以下のクリープ試験条件では，そのク 

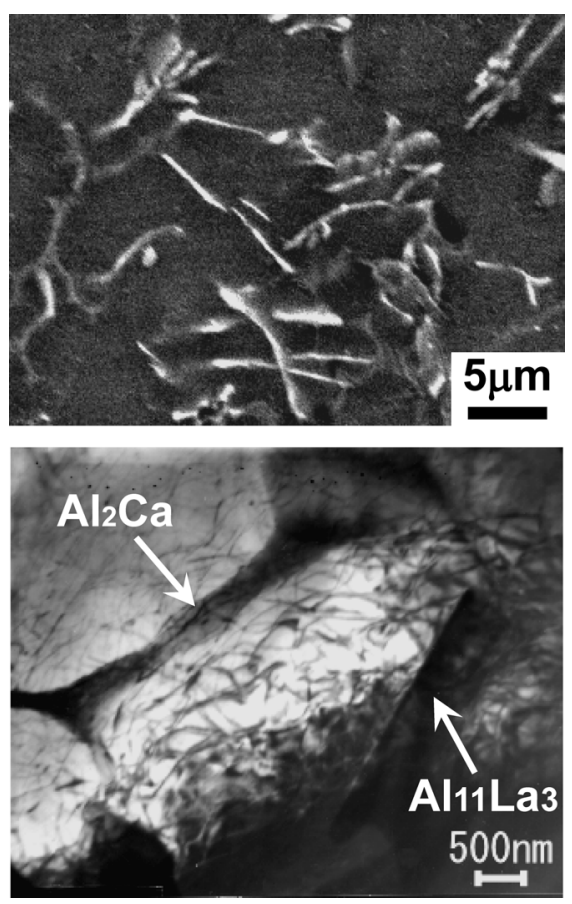

図 $241200 \mathrm{~h}$ クリープ試験したZAXLa05613 合金ダイカ スト材の SEM 像および TEM 像 試験温度 : $175^{\circ} \mathrm{C}$, 負荷応力 : $50 \mathrm{MPa}$

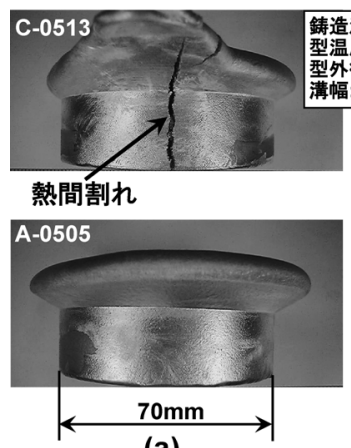

(a)

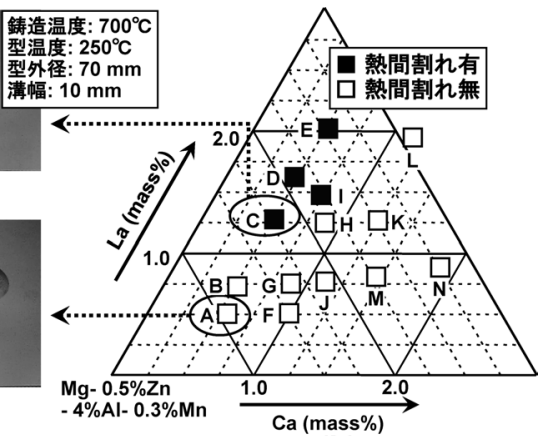

(b)
図 25 リング割れ試験結果ならびに熱間割れ試験後の概観

リープ特性は現在エンジン周りに使用されているダイカスト 用アルミニウム合金に匹敵する。

\section{2 .3 熱間割れ感受性の低減}

熱間割れは粒界に晶出する化合物が多くなるほど生じやす いと言われている。そこで, $\mathrm{Mg}-0.5 \% \mathrm{Zn}-4 \% \mathrm{Al}-0.3 \% \mathrm{Mn}$ 合金 をべース合金として，La 量を $0.5 \sim 2.0 \%$, Ca 量を $0.5 \sim 1.8 \%$ の 範囲で変化させて，熱間割れ感受性を評価した ${ }^{69)}$ 。

図 25 に本検討合金の熱間割れリング試験結果を示す。リ ング試験は，外径 $70 \mathrm{~mm}$, 溝幅 $10 \mathrm{~mm}$ のリング試験用金型を 用い, 溶湯鋳込み温度約 $700^{\circ} \mathrm{C}$, 金型温度約 $250^{\circ} \mathrm{C}$ の条件で 行った。 La 量が 1.3 mass \% 以上で，かつ Ca 量が 0.8 mass $\%$ 以下の合金で熱間割れが発生した。このことは $\mathrm{Al}_{11} \mathrm{La}_{3}$ 化合 物の晶出が熱間割れに密接に関連することを示唆している。 図中には熱間割れが発生した C-0513 合金と発生しなかった A-0505 合金のリング試験片外観写真を示しているが，熱間割 れは最終凝固部となる 1 か所で下から上まで貫通するように 発生する。図 26 は熱間割れが発生した C-0513 合金の破面お
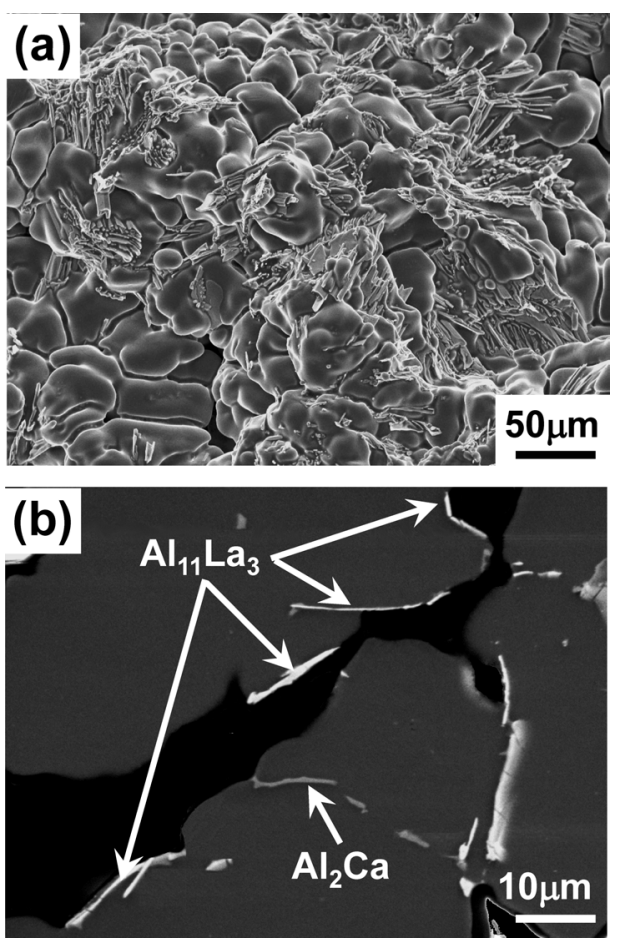

図 $26 \mathrm{Mg}-0.4 \mathrm{Zn}-4 \mathrm{Al}-0.3 \mathrm{Mn}-0.5 \mathrm{Ca}-1.3 \mathrm{La}$ (mass \%, C-0513) 合金リング試験片の熱間割れ表面の（a）SEM 像 および（b）その近傍のミクロ組織

(a) La添加量変化合金

(b) Ca添加量変化合金

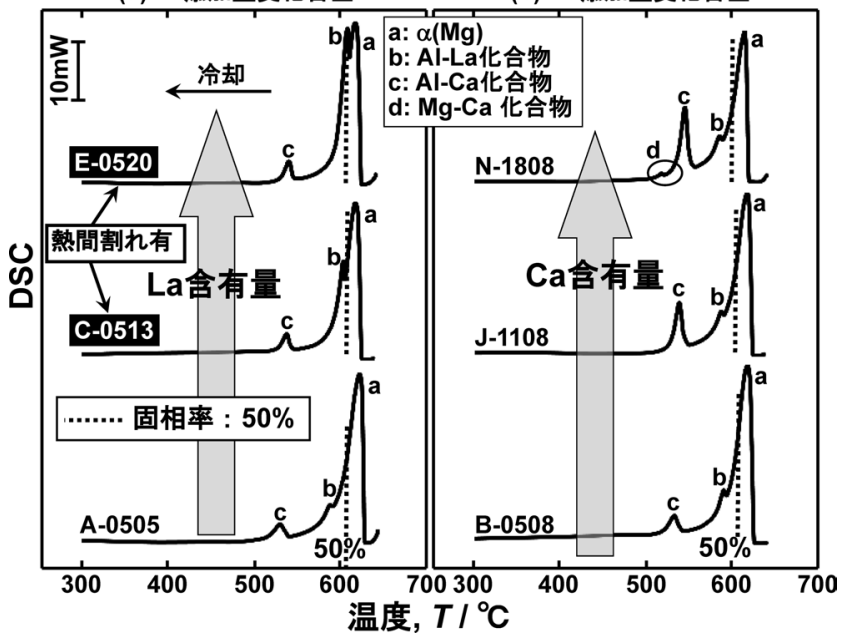

図 $27 \mathrm{Mg}-0.5 \mathrm{Zn}-4 \mathrm{Al}-0.3 \mathrm{Mn}$ (mass\%) 合金の各晶出相 に及ぼす La および Ca の影響。合金組成は図 25 参照のこと

よび破面近傍のミクロ組織である。写真（a）に示すように， 表面に滑らかなデンドライトアームが観察されることから， 凝固収縮の際に割れが発生しているものと推測される。また, 写真（b）に示すように, 割れの表面には, $\mathrm{Al}_{11} \mathrm{La}_{3}$ 針状化合 物が観察され，割れは針状化合物に沿って伝播する。このこ とは, 凝固収縮時に粒界に層状に晶出する $\mathrm{Al}_{11} \mathrm{La}_{3}$ 化合物之 マトリックスとの界面で割れが発生し，針状化合物に沿って 進展することを示している。図 27 に代表的な検討合金の冷 却時の示差熱量分析曲線（以下 DSC 曲線と記す）を示す。 検討合金は凝固時にマグネシウム固溶体， $\mathrm{Al}_{11} \mathrm{La}_{3}$ 化合物， $\mathrm{Al}_{2} \mathrm{Ca}$ 化合物の順に晶出する。通常, 凝固過程では固相率が 
40 50\% で，凝固殼が強度を発生するようになると言われて いる ${ }^{76)}$ 。50\%の固相率に対応する温度を凝固時の発熱量が全 発熱量の $50 \%$ に達する温度と仮定して求め, 図中に示して いる。熱間割れが発生する合金ではその温度は $\mathrm{Al}_{11} \mathrm{La}_{3}$ 化合 物が晶出する温度と重なり，熱間割れが発生しない合金では $\mathrm{Al}_{11} \mathrm{La}_{3}$ 化合物が晶出する前に固相率が $50 \%$ に達し, すでに 凝固殻が強さを発生するようになる。以上の結果から，凝固 殼が強度を有するようになる温度で $\mathrm{Al}_{11} \mathrm{La}_{3}$ 化合物が晶出す る発熱反応により凝固が停滞し，しかむマグネシウム固溶体 のデンドライトアーム間に $\mathrm{Al}_{11} \mathrm{La}_{3}$ 化合物が分離共晶化合物 として層状に晶出するため, 凝固収縮時にその界面から割れ が発生し，伝播しやすくなるものと考えられる。以上のこと から，熱間割れを回避するためには，固相率が 40 50\% で共 晶反応のような発熱反応が生じないような合金選択をする必 要がある。

本節では, 自動車のエンジン周りの部品へ適用可能なマグ ネシウム合金の開発研究の流れを耐熱性と凝固時の熱間割れ を中心に述べた。これらの特性を両立するためには，粒界化 合物の種類, 量, 形態を制御することが重要である。 $\mathrm{Mg}-\mathrm{Zn}-$ Al-Ca-RE 系合金では粒界に晶出する Al-RE 系および Al-Ca 系化合物がクリープ特性を向上させる。Al-RE 系化合物とし ては, 粒状の $\mathrm{Al}_{2} \mathrm{RE}$ および針状の $\mathrm{Al}_{11} \mathrm{RE}_{3}$ 化合物が晶出する が，従来から使用されている軽希土類元素の混合物である MM から La 単独添加に变えることにより，熱的安定性に優 れる $\mathrm{Al}_{11} \mathrm{La}_{3}$ 針状化合物が晶出するようになり，クリープ特 性はさらに改善される。一方, 熱間割れを抑制するためには, 凝固時のマグネシウム固溶体のデンドライトアームが成長・ 連結し，凝固殼が強さを発生した後にこれらの化合物が晶出 するような合金組成を選択する必要がある。

実際の実用化・事業化に際しては量産化に伴う問題等が残 されている。本研究成果が今後, 更なる改良に際して有益と なることを期待する。

\section{3 組織制御によるマグネシゥム合金の加工性および機 械的性質の改善}

マグネシウムは構造用実用金属材料の中で比強度が高く, かつ軽量化材として輸送機器等に多用されている樹脂等と比 較するとリサイクルが容易であることから，環境に優しい 21 世紀のキーマテリアルとして期待され, 国内では電子機器の 筐体を中心として，欧米では大型自動車部品など，民生用部 品への適用が拡大している。国内でも自動車部品として, オ イルパン, トランスミッションケース等のエンジン周り, ス テアリングホイール， シートフレーム，インスッルメントパ ネル等の内装品への応用が始まっている。その背景には, 欧 州では，規制として 2008 年までに自動車からの $\mathrm{CO}_{2}$ 排出量 を $140 \mathrm{~g} / \mathrm{km}$ 以下までの削減を予定しており，さらに 2012 年 には $120 \mathrm{~g} / \mathrm{km}$ まで低減させるような動きもある。一方，国内 でも 2010 年には燃費基準の見直しを予定している。そのよ うな規制がマグネシウム合金使用の機運に拍車を駆けている。 ただし，図 28 に示すように，設計要件として曲げ剛性が必 要とされる場合, マグネシウム合金使用による軽量化はアル ミニウム合金，鉄鋼材料に対して大きな優位性を有するもの の, 耐力が設計要件として必要とされる場合, ダイカスト材 ではアルミニウム合金より劣り, 軽量化は難しい。展伸材で あればその優位性を維持できるものの，マグネシウム合金製

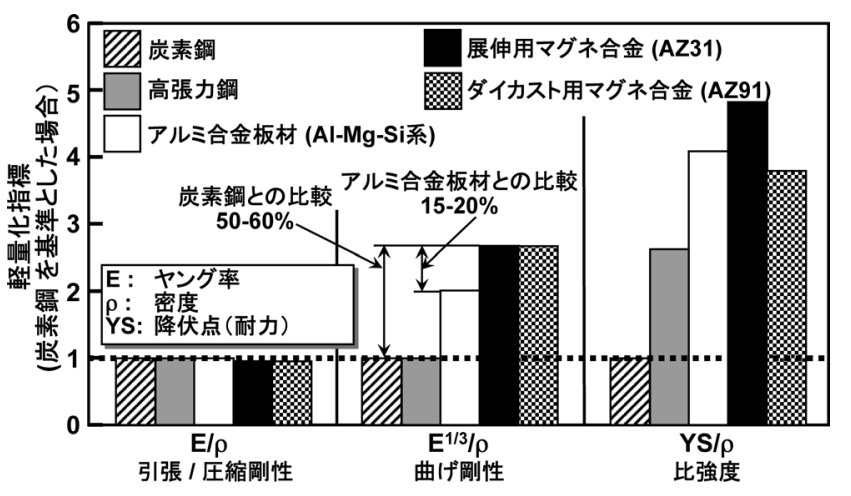

図 28 各種金属材料の軽量化指標の比較

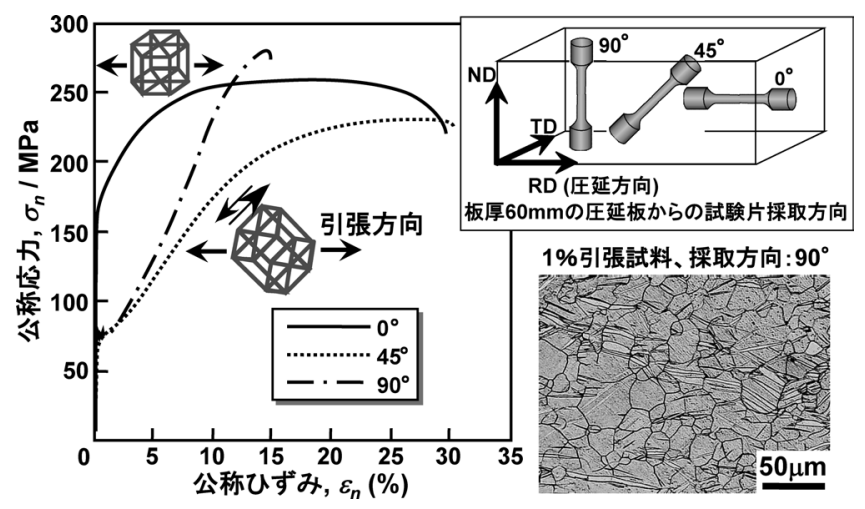

図 $29 \mathrm{AZ} 31$ マグネシウム合金圧延材の引張特性の室温 異方性

実部品の寸法が大きくなれば，その回りの部品む大きくなり， その結果, 軽量化効果が発揮できなくなる可能性むある。そ のため, 自動車部品への応用を考えた場合, すでに使用され ている鉄鋼材料, アルミニウム合金と同程度まで強度特性, 特に耐力を向上させる必要がある。そのようなこともあり, より高性能な部材創製を目指した材料開発およびプロセス技 術開発が産業界, 大学等の研究機関で積極的に進められてい る。本節では, 熱間加工時の变形挙動の理解のための基礎と なる变形機構, ならびにここ数年の国内外における熱間加工 によるマグネシウム合金素材の組織制御技術について述べる。

3.3.1 マグネシウム合金の変形挙動

マグネシウム合金の軽量性を生かした部材製造のためには, 変形機構, 組織形成機構のような本質的理解に基づいたプロ セス開発および部材設計が必要となる。単相組織のマグネシ ウム合金多結晶体では, 室温でも底面すべりに加え, 粒界近 傍では非底面すべりおよび粒界すべりが，さらには变形初期 には引張双晶が，破断直前には圧縮双晶屯変形に寄与し，ひ ずみ速度が小さい場合には回復さえ生じることが明らかにさ れている33,5),77)。この結果は, 結晶粒径を小さくすることによ り, 結晶粒内全体に非底面すべりを生じさせ, 変形能を向上 させ得ることを意味する。ただし，圧延集合組織のように， 圧延面が底面配向した組織では板厚方向の变形が抑制される ため，板材の室温加工を改善するためには結晶粒のランダム 配向化が必要である。

また，図 2978),79) に示す AZ31 マグネシウム合金圧延板のよ うに，底面が圧延面に平行に強く集積するような集合組織を 形成する場合, 圧延方向から板厚方向に $0^{\circ}, 45^{\circ}, 90^{\circ}$ と傾斜さ 


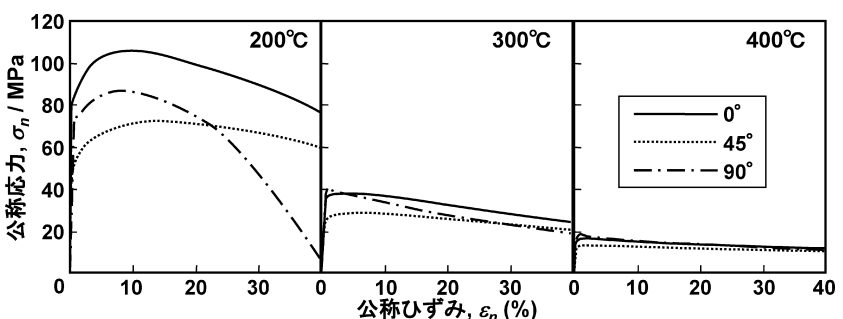

図 $30 \mathrm{AZ} 31$ マグネシウム合金圧延板の応力ーひずみ曲 線（ひずみ：40\%まで）の温度依存性 試験片採取方向は図 2 と同じ

せて試験片を用いて室温で引張試験すると, 応力ーひずみ曲 線は大きく異なる。このような異方性は，45方向から採取 した試験片では底面すべりが，90方向から採取した試験片 では引張双晶が容易に生じるため，圧延方向と平行な $0^{\circ}$ 方 向から採取した試験片と比較すると, 耐力は約 $1 / 2$ まで低下 する。ただし， $45^{\circ}$ 方向から採取した試験片の伸びは約 $30 \%$ と， $0^{\circ}$ 方向とほぼ同程度で，大きな延性を示す。一方， $90^{\circ}$ 方向から採取した試験片は, 降伏後, 大きな加工硬化を示 し，伸びは $15 \%$ と他の方向から採取した試験片と比較する と半分程度にまで減少する。これは, 粒内で生じる引張双晶 により，底面が約 $86^{\circ}$ 屯傾き，その双晶内部で底面すべりが 生じるものの, マトリックスとの界面に転位が堆積するため, 著しい加工硬化を示し, その界面から亀裂が発生し, 延性は 大きく低下することになる。ただし，図 30 の応力ーひずみ 曲線の温度依存性に示すように，このような大きな異方性は $300^{\circ} \mathrm{C}$ 以上では軽減する。マグネシウム合金の圧延, 鍛造, 押出等が $300 \sim 400^{\circ} \mathrm{C}$ で行われるのは，このような理由による。

\subsection{2 マグネシウム合金の結晶粒微細化とその効果}

金属材料の強度と延性を両立する方法として結晶粒微細化 が挙げられるが，六方晶金属であるマグネシウム合金の場合， その構造に起因して，結晶粒微細化効果が他の合金より大き いことが知られている。マグネシウム合金では室温での塑性 加工は困難を伴うが，温間および熱間加工ではアルミニウム 合金並みの加工性を有するとともに，動的再結晶が生じやす く, その結果, 結晶粒微細化も比較的容易に達成できる。 AZ31 合金のようなマグネシウム固溶体単相からなる合金の 動的再結晶は, 立方晶で生じる機構とは異なり, 变形に伴う キンク帯の形成とそれによる結晶粒の分割という動的な連続 再結晶であり ${ }^{80)}$ ， その後の焼なましにより回復を伴った粒成 長のみが生じる静的な連続再結晶が生じ，集合組織そのもの は変化しないと言われている81)。その機構から, 結晶粒の微 細化方法として，1 パスごとに加工温度を下げながら，互い に直行する三軸方向を圧縮する降温多軸鍛造を行い, サブミ クロンオーダの結晶粒が得られている ${ }^{82)}$ 。同様な方法として, 1 パスごとに $90^{\circ}$ 回転させる $\mathrm{ECAE}$ 加工 ${ }^{83), 84)}$, 粗粒粉末を用 いた反復式塑性加工を施す「餅つき加工」年) でも微細粒が得 られる。一方, AZ61 合金のような高アルミニウム含有合金 を $200^{\circ} \mathrm{C}$ 以下で $\mathrm{ECAE}$ 加工すると, 図 3193) に示すように加 工中に $100 \mathrm{~nm}$ 程度の球状の $\mathrm{Mg}_{17} \mathrm{Al}_{12}$ 相 $(\beta)$ が同時に動的析 出し, それらのピン止め効果により再結晶粒の粗大化が顕著 に抑制され, サブミクロンオーダまでの結晶粒微細化が達成 できる。その結果, 図 3283) に示すように, 耐力が $300 \mathrm{MPa}$ 以上でありながら, 伸びあ $30 \%$ 以上と, 実用アルミニウム合

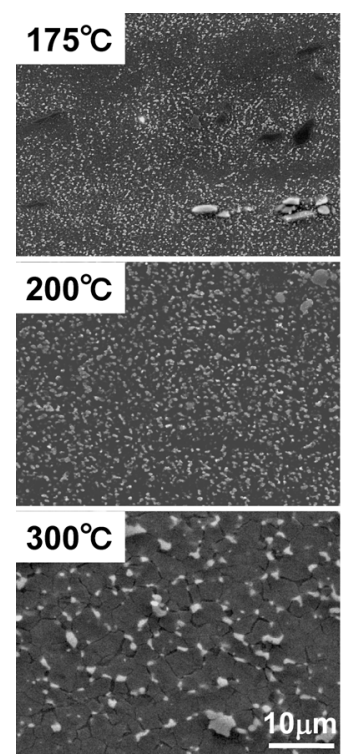

$175^{\circ} \mathrm{C}-4$ パス ECAE材 平均粒径: $0.5 \mu \mathrm{m}$

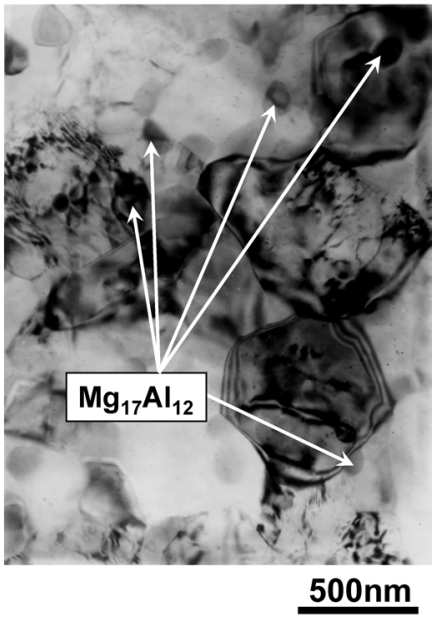

図 31 各温度で 4 パス $\mathrm{ECAE}$ 加工した AZ61 マグネシウ ム合金の SEM 像打よび $175^{\circ} \mathrm{C} \mathrm{ECAE}$ 加工材の TEM 像

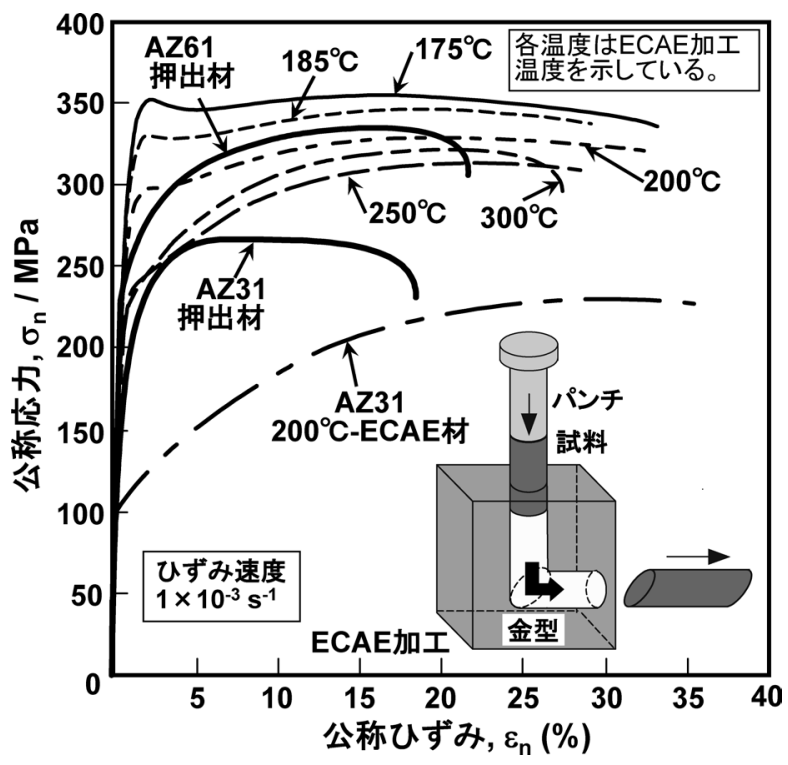

図 $32 \mathrm{ECAE}$ 加工した AZ61 マグネシウム合金の応力ー ひずみ曲線

金 6061-T6 処理材以上の高強度・高延性を示すようになる。 このような高強度化は, 図 33 に示すように, 主に動的析出 した球状の $\beta$ 相と結晶粒微細化の相乗効果によるものであ る。さらに, 本合金素材のように結晶粒が超微細化すること により，図 $34^{84)}$ に示すような低温超塑性および $250^{\circ} \mathrm{C}$ 程度 の比較的低温での高速超塑性む発現する。

3.3.3 既存加工プロセスによる高強度化, 易加工性を目 指した研究開発

（1）熱間加工を利用した結晶粒微細化 + 動的析出 + 化合 物微細分散型マグネシウム合金押出材の高強度・高延 性化および異方性低減

自動車の構造材としてマグネシウム合金を用いる場合，コ スト面から押出加工が有利であるが, 軽量化を達成するため 


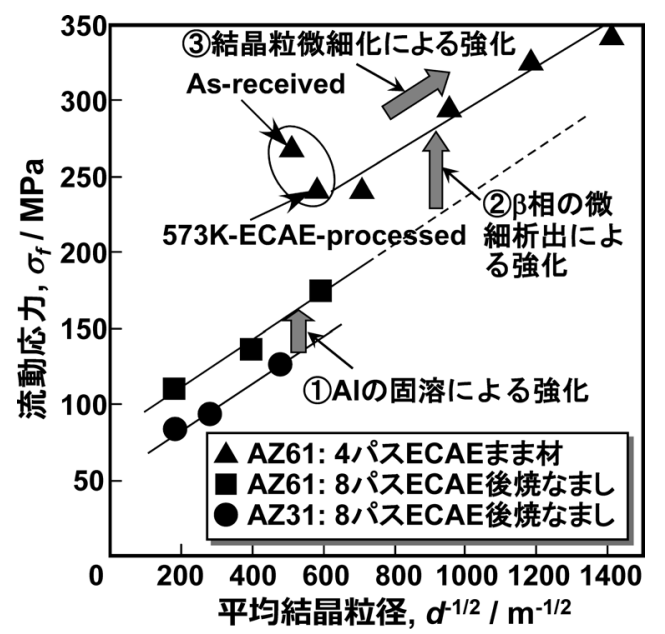

図 33 ひずみ $2 \%$ における流動応力の粒径依存性

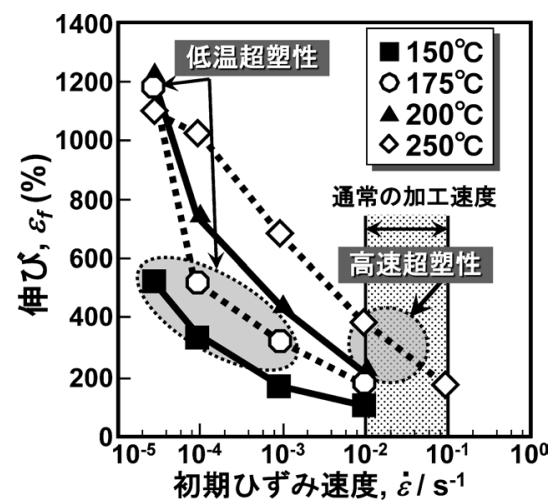

図 $34 \mathrm{ECAE}$ 加工した AZ61 マグネシウム合金の高温延 性のひずみ速度依存性

にはアルミニウム合金に匹敵する高強度・高延性が必要とさ れる。それを達成する手法として，3.3.2でも述べたような熱 間加工中に生じる動的析出と動的再結晶の組合せが考えられ る。ただし, 押出温度は $300^{\circ} \mathrm{C}$ 以上が一般的でああるので, そのような温度でも析出が生じるように，さらにアルミニウ 厶含有量を増やす必要がある。例えば，図 35 $5^{79)}$ に示すよう に， $\mathrm{Mg}-7 \sim 9 \% \mathrm{Al}-1 \% \mathrm{Zn}$ 合金に微量の $\mathrm{Ca}$ および希土類元素 （La）を添加した合金の場合， $400^{\circ} \mathrm{C}$ では両合金とも結晶粒径 に変化がないのに対し， $300^{\circ} \mathrm{C}$ では $\mathrm{Al}$ 含有量の増加に伴い動 的析出・動的再結晶が促進され，その結果として結晶粒径が 微細化する。また，図 36 $6^{79)}$ に示すように，これらの押出材 に人工時効（T5）処理を施すことで粒内および粒界に微細な ラメラ状の $\beta$ 相が多量に析出する。時効による析出量は押出 温度が高く，かつ $\mathrm{Al}$ 含有量の多い屯のほど多くなり，時効 硬化量む大きくなる。その結果，高 $\mathrm{Al}$ 含有合金を高温で押 出すると, 図 3779) に示すように, 引張強さ, 耐力は高くな るが，破断伸びは低下する。ちなみに， $400^{\circ} \mathrm{C}$ での押出後， $200^{\circ} \mathrm{C}-16 \mathrm{~h}$ の時効処理を施した $\mathrm{AZ} 91+0.1 \% \mathrm{Ca}+0.5 \% \mathrm{La}$ 合金 押出 $\mathrm{T} 5$ 処理材は引張強さ $370 \mathrm{MPa}, 0.2 \%$ 而力 $255 \mathrm{MPa}$, 伸 び $16.5 \%$ と，6N01 アルミニウム合金押出 T5 処理材と同等以 上の引張特性を有する。ただし, 押出温度を $400^{\circ} \mathrm{C}$ から $300^{\circ} \mathrm{C}$ へ低下させると, 図 35 にあ示したように結晶粒径が 微細になるにもかかわらず， $0.2 \%$ 而力打よび引張強さとも低 下する。その原因として集合組織の影響が考えられることか
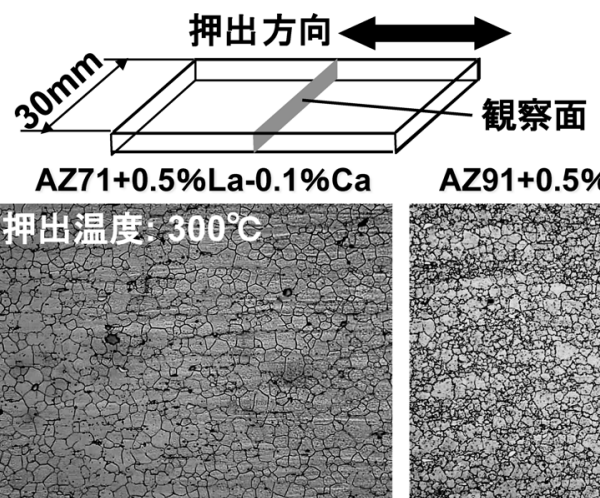

$\mathrm{AZ91}+0.5 \% \mathrm{La}-0.1 \% \mathrm{Ca}$
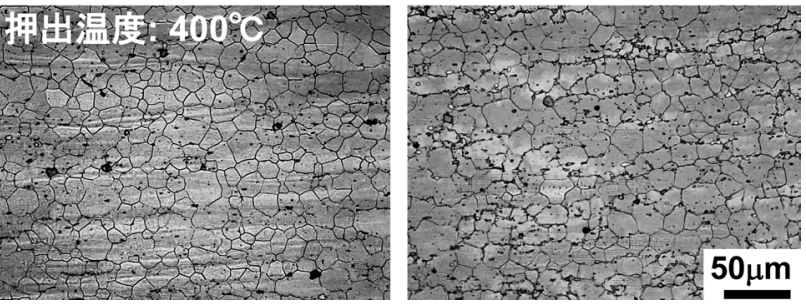

図 $35 \mathrm{Mg}-7 \sim 9 \mathrm{Al}-1 \mathrm{Zn}-0.1 \mathrm{Ca}-0.5 \mathrm{La}(\mathrm{mass} \%)$ 合金押出 材のミクロ組織に及ぼす押出温度およびアルミニ ウム含有量の影響

押出まま材
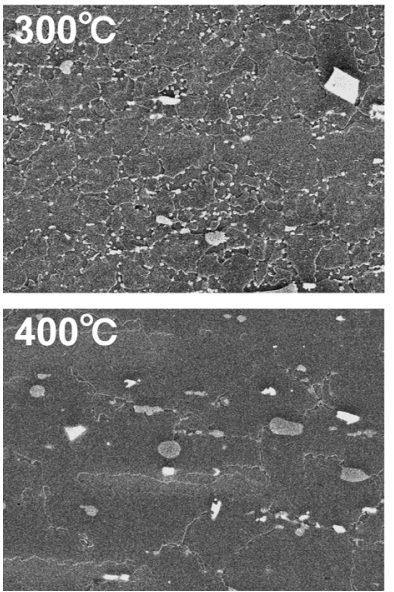

図 $36 \mathrm{Mg}-9 \mathrm{Al}-1 \mathrm{Zn}-0.1 \mathrm{Ca}-0.5 \mathrm{RE}(\operatorname{mass} \%)$ 合金の T5 処 理によるミクロ組織変化

RE はミッシュメタル (MM) で添加

ら，EBSP により各結晶粒の配向を調べ，引張方向となる押 出方向に対する底面すべり $(0001)\langle 11 \overline{2} 0\rangle$ のシュミット因子 を調べた。図 3879) に各結晶粒のシュミット因子およびその 分布を示す。押出温度 $300^{\circ} \mathrm{C}$ では $400^{\circ} \mathrm{C}$ に比べて, 押出方向 に底面が傾いた結晶粒，すなわちシュミット因子の大きい結 晶粒の体積率が多い。このことは, 押出温度 $300^{\circ} \mathrm{C}$ では底面 すべりが活動しやすい結晶粒が多いことを意味し， $0.2 \%$ 耐力 の低下の原因と考えられる。そこで，集合組織变化に伴う耐 力の変化を定量的に評価するため, 図 3979) に示すように, 各試料の平均シュミット因子の逆数と, 従来から報告されて いるホールペッチ式による結晶粒微細化効果分を $0.2 \%$ 耐力 から差引いた值の関係を調べた。その結果，押出まま材（F 材）抢よび $\mathrm{T} 5$ 処理材とも強い相関を示し，今回検討した押 出温度の变化に伴う集合組織の变化により, $9 \% \mathrm{Al}$ 添加合金 では約 $50 \mathrm{MPa}$ も耐力が変化し, その影響が大变大きいこと 
が確認された。

また，既存の AZ31 合金押出材，圧延材では，押出あるい は圧延方向に対して圧縮応力が加わった場合，図 29 に示し たように， c 軸引張双晶变形が低応力で生じ，引張耐力に対 する圧縮耐力の比が 0.5 程度にまで低下することが知られて いる。このことが，展伸材使用に際しての設計自由度を極端 に狭めている。上記のような動的析出を伴った動的再結晶を 発現させた合金でも同様な圧縮耐力の低下が生じる可能性も あることから，高耐力を示した AZ91 合金およびそれに $0.1 \%$ Ca および 0.5\% La を添加した合金の押出まま材および T5 処 理材の押出方向における引張耐力と圧縮耐力を測定し, その

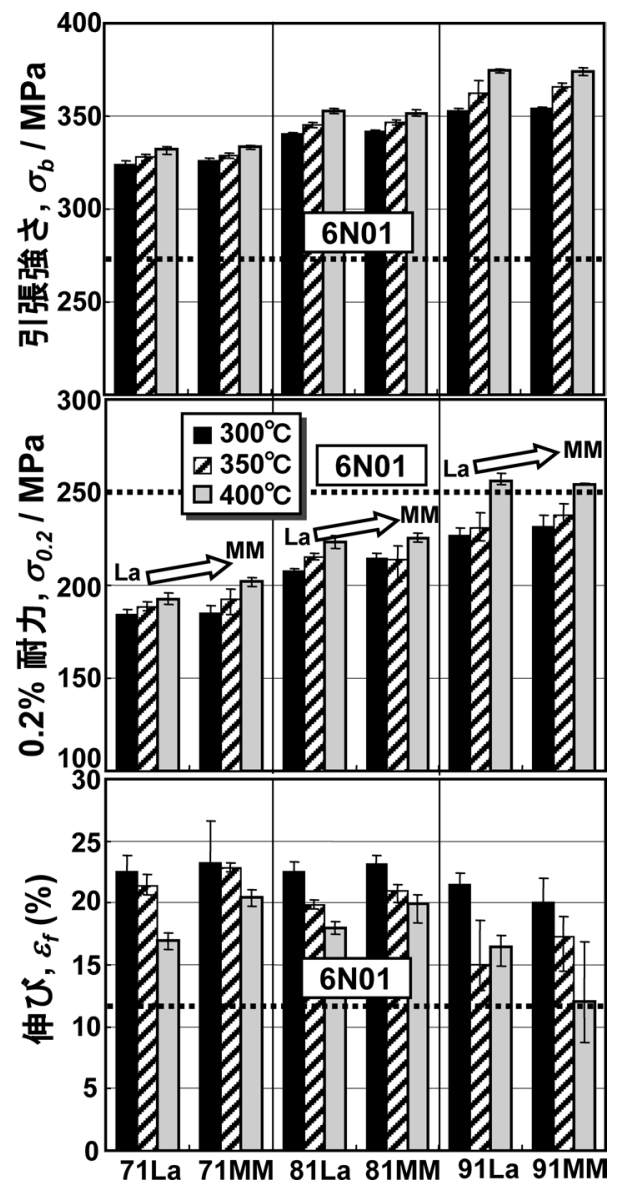

図 $37 \mathrm{Mg}-7 \sim 9 \mathrm{Al}-1 \mathrm{Zn}-0.1 \mathrm{Ca}-0.5 \mathrm{MM}$ あるいは $\mathrm{La}$ (mass \%) 合金押出 T5 処理材の室温引張特性
比を評価した。その結果を図 40 ${ }^{78), 79)}$ に示す。両合金とも, 押出まま材では $300^{\circ} \mathrm{C}$ 押出材の圧縮耐力/引張耐力が 0.9 以上 と大きな值を示すが， $350^{\circ} \mathrm{C}$ 押出材では引張耐力は $300^{\circ} \mathrm{C}$ 押 出材とほぼ同等であるものの, 圧縮耐力は $175 \mathrm{MPa}$ まで低下 し, その比は 0.75 まで低下する。一方, T5 処理材は押出温 度にかかわらず圧縮耐力, 引張耐力とも高い值を示し，その 比は約 1 となる。図 41 ${ }^{78), 79)}$ に $350^{\circ} \mathrm{C}$ 押出材の圧縮变形およ び引張变形における応力 -ひずみ曲線を示す。両合金の F 材 および $\mathrm{T} 5$ 処理材とも圧縮変形時の応力ーひずみ曲線の形状 は変わらず，双晶変形特有の大きな加工硬化を示す。ただ し, T5 処理材の圧縮耐力は顕著に向上し, 引張耐力とほほ 同等となる。以上のことから, 低温押出時の動的析出物, あ るいは押出後の時効析出物により, 引張双晶発生のための応 力が顕著に向上し，圧縮耐力/引張耐力が約 1 にまで上昇す るものと結論される。このことは, 耐力の異方性のない高強 度合金開発の方向として, 析出強化型合金の開発が有効であ ることを示している。なお, $\mathrm{Mg}-\mathrm{Zn}-\mathrm{Zr}$ 系 ${ }^{86), 87)}, \mathrm{Mg}-\mathrm{Zn}-\mathrm{Mn}$ 系 ${ }^{88)}, \mathrm{Mg}-\mathrm{Al}-\mathrm{Ca}$ 系 ${ }^{89) ~ 91)}, \mathrm{Mg}-\mathrm{Sn}-\mathrm{Zn}-\mathrm{Al}$ 系 ${ }^{92)}$ をべースとし た合金系でも，動的析出を伴う動的再結晶が生じ，動的析出 物のピン止め効果による結晶粒微細化効果之微細析出物その

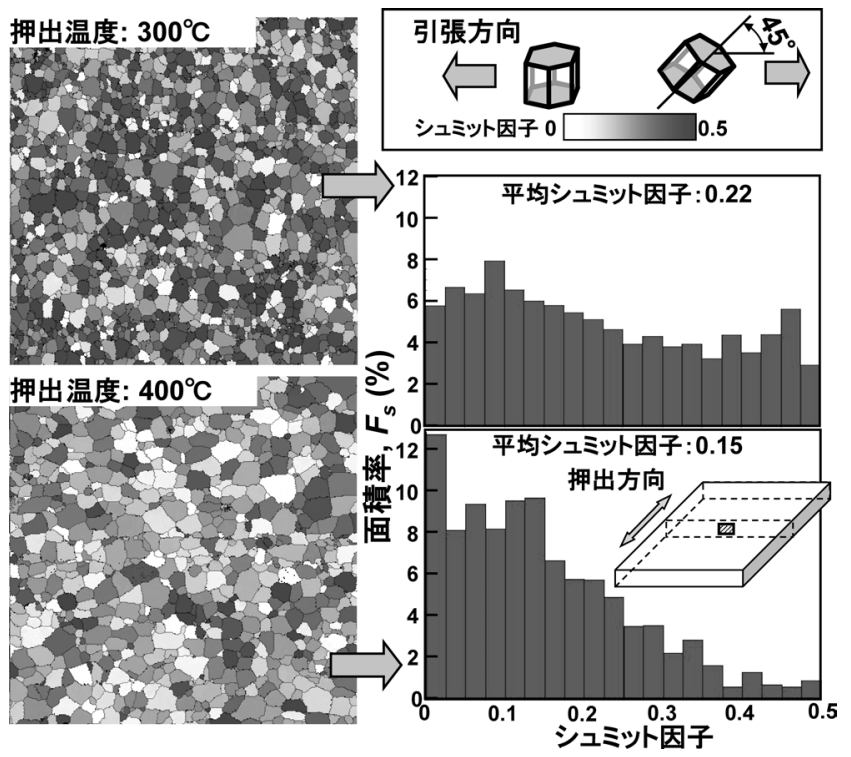

図 $38 \mathrm{Mg}-9 \mathrm{Al}-1 \mathrm{Zn}-0.1 \mathrm{Ca}-0.5 \mathrm{La}(\operatorname{mass} \%)$ ) 合金押出材の 引張方向に対する底面のシュミット因子の分布

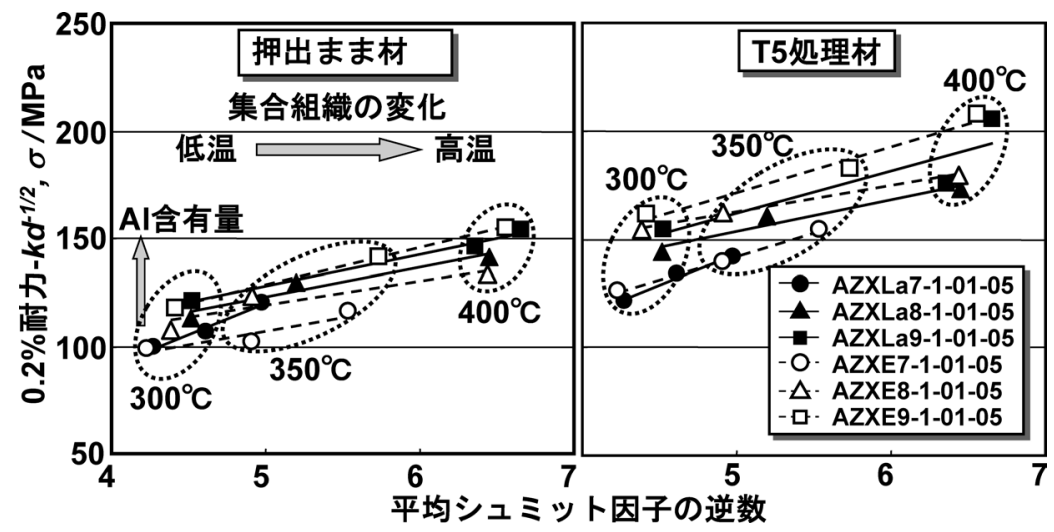

図 39 平均シュミット因子と耐力の関係 

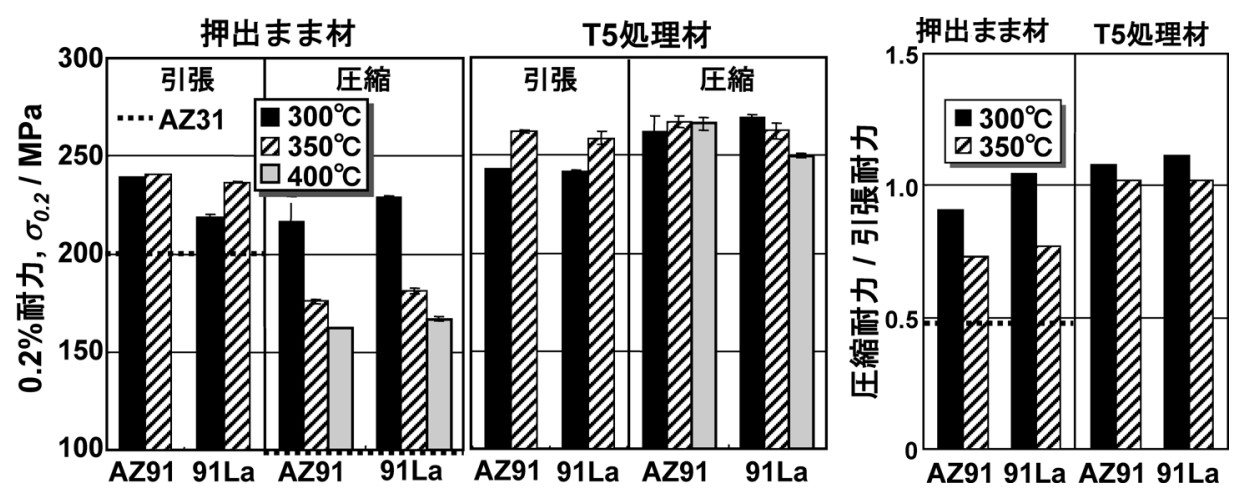

図 40 AZ91 合金および $\mathrm{Mg}-9 \mathrm{Al}-1 \mathrm{Zn}-0.1 \mathrm{Ca}-0.5 \mathrm{La}$ (mass\%) 合金押出材の引張・圧縮耐力

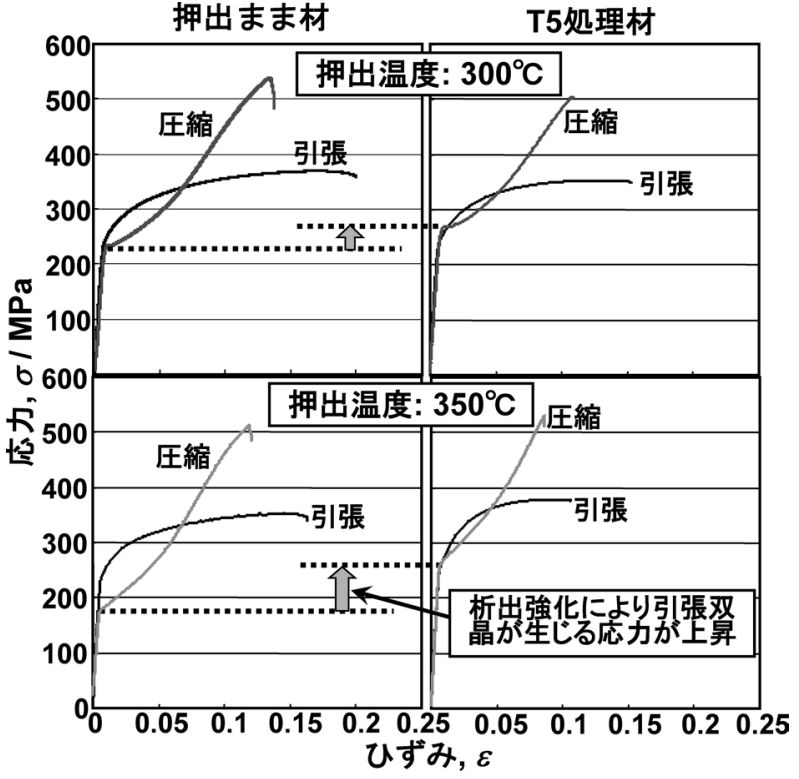

図 41 AZ91 合金押出材の引張・圧縮ーひずみ曲線

ものによる析出強化の相乗効果により高強度，かつ適度な延 性および耐力の低異方性を発現するようになることがわかっ てきている。

（2）熱間圧延中の動的析出を利用した結晶粒微細化による 高強度・高延性化抢よび成形性改善

$\mathrm{Mg}-\mathrm{Al}-\mathrm{Mn}$ 系合金の $\mathrm{Al}$ 量を $5.0 \sim 6.0 \%$ と変化させた合金を 圧延パスごとに温度を $400^{\circ} \mathrm{C}$ から $300^{\circ} \mathrm{C}$ 程度にまで低下させ ながら圧延すると，図 42 ${ }^{78), 79)}$ に示すように， $\mathrm{Al}$ 量を $6 \%$ ま で増やすことにより, 圧延中に粒状の $\mathrm{Mg}_{17} \mathrm{Al}_{12}$ 相の動的析出 と動的再結晶が同時に生じ, 平均結晶粒径 $6 \mu \mathrm{m}$ 程度の, 均 一かつ微細な動的再結晶粒が形成される。その結果, 図 43 78,79) に示すように室温では既存 AZ31 合金より高強度であ

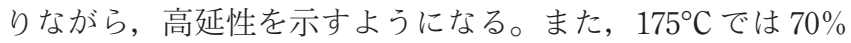
以上， $225^{\circ} \mathrm{C}$ では， $120 \%$ 以上の高延性を示すようになる。し かむ, $200^{\circ} \mathrm{C}$ 以上では変形中の動的再結晶に伴う結晶粒微細 化が生じ, 粒界すべりの寄与による板厚方向の変形も可能と なり，等方的な変形が生じ，ランクフォード值（r 值）は 1.0 に近くなる。その結果, $6 \% \mathrm{Al}$ 添加合金では $200^{\circ} \mathrm{C}$ でも限界 絞り比（LDR） 2.8 と既存 AZ31 合金を上回る。

本節ではマグネシウム合金の特徴とも言える，熱間加工中 の複雑に絡み合った動的なミクロ組織变化とその特徵を生か したミクロ組織制御を中心に述べ，その結果として動的析出
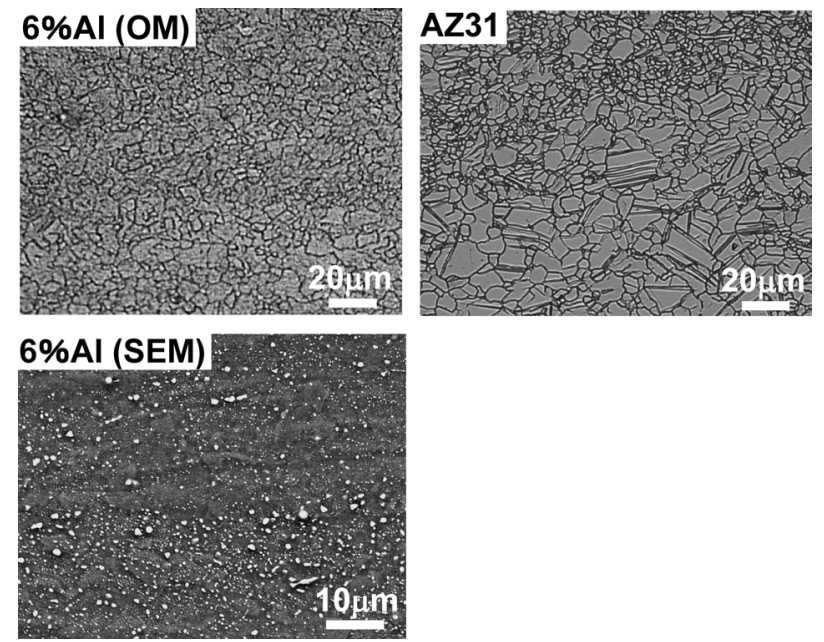

図 $42 \mathrm{Mg}-6 \% \mathrm{Al}-0.15 \% \mathrm{Mn}$ 合金圧延材のミクロ組織

物が生じるような低温・低速で押出をすることにより, 再結 晶粒径を数ミクロン以下の結晶粒径にまで容易に達成でき, 高強度・高延性化が可能であることを示した。今後, 上述し たような組織制御技術屯念頭に入れて, 各製造プロセスの特 徵を生かす合金開発，あるいはすでに開発されているマグネ シウム合金のポテンシャルを引出すプロセス技術開発の両観 点からの研究を進めて頂けたら幸いである。今後, 展伸材に ついては素材創製プロセス技術，例えば連続鋳造によるスラ ブ，ビレット製造と加工プロセスの工程数削减を図り，コス 卜的にも安価に製造する技術の確立が急務である。さらに品 質および量とも確保できなければ, 輸送機器への応用という 未来は開けないであろう。一方, 最終製品にするための接合 技術，表面処理技術も確立しなければならない。実用化のた めには, 材料特性としての变形の異方性, 衝突安全性, 疲労 強度, 応力腐食割れ等の改善屯必要となる。

\section{4 マグネシゥム合金のリサイクル技術}

3.4.1 Al-Mn 添加および鎮静による不純物除去

マグネシウム合金に Fe が多量に混入すると, 耐食性が著 しく低下することから ${ }^{93)}, \mathrm{Mg}-3 \% \mathrm{Al}-1 \% \mathrm{Zn}$ 展伸用合金 （AZ31 合金）の ASTM 規格では，比較的耐食性の良好な夕゙ イカスト用 AZ91D 合金と同様に, Fe 量を $50 \mathrm{ppm}$ 未満に規定 している。実用化されている $\mathrm{Mg}-\mathrm{Al}$ 系および $\mathrm{Mg}-\mathrm{Al}-\mathrm{Zn}$ 系合 金では，相当量の Mn 添加を行い，鋳造時に形成される $\mathrm{Al}-\mathrm{Mn}$ 化合物中に Fe を固溶させるとともに, マグネシウム 合金溶湯と溶湯中に浮遊している $\mathrm{Al}-\mathrm{Mn}$ 系化合物の比重差 

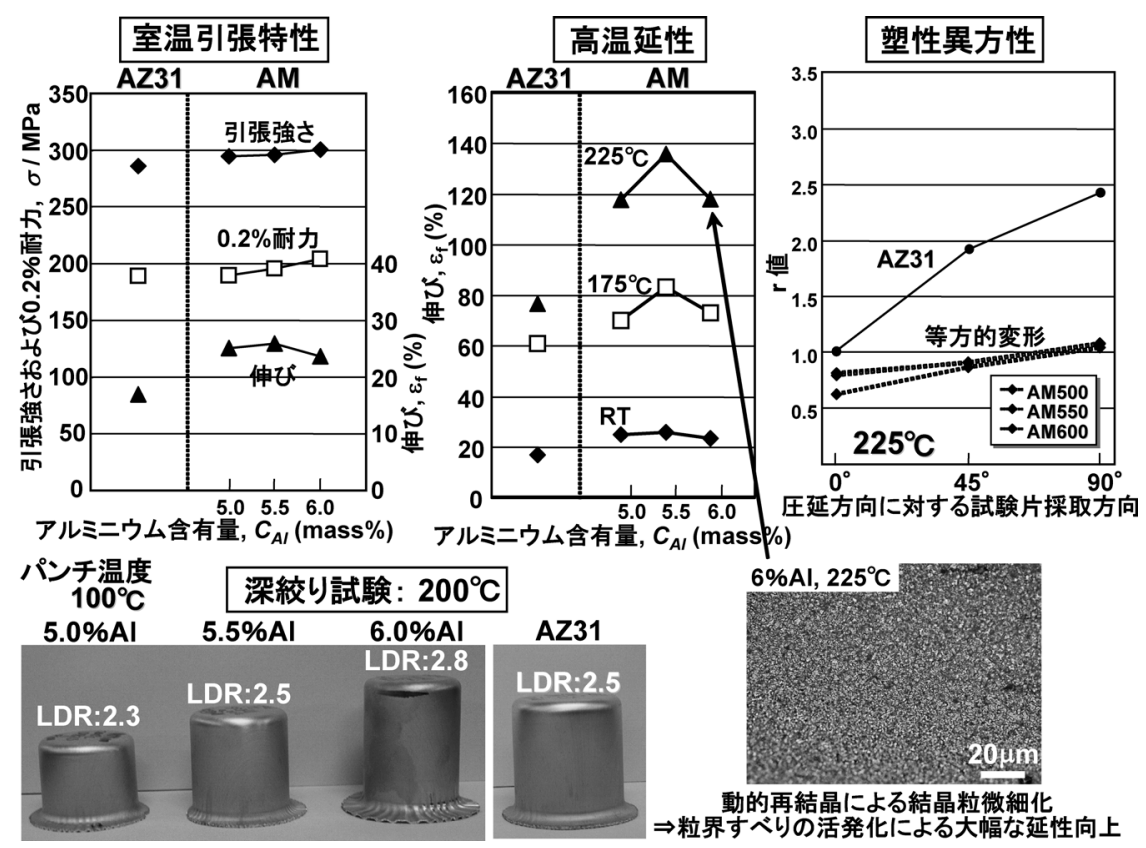

図 $43 \mathrm{Mg}-5.0 \sim 6.0 \mathrm{Al}-0.15 \mathrm{Mn}$ (mass\%) 合金圧延材の室温引張特性, 高温延性, 塑性異方性㧍よび深絞り性

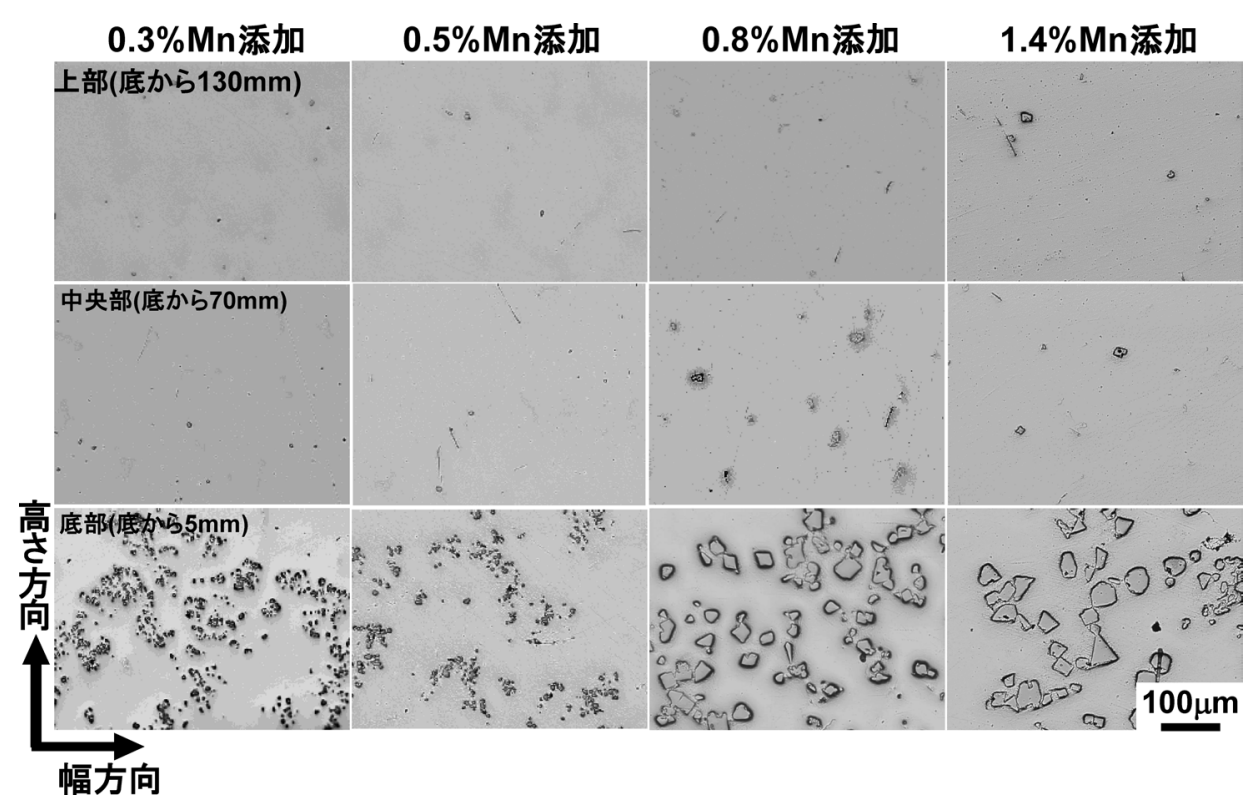

図 $44 \mathrm{Mg}-3 \mathrm{Al}-1 \mathrm{Zn}(\mathrm{mass} \%)$ 合金溶湯を $650^{\circ} \mathrm{C}$ で $20 \mathrm{~min}$ 鎮静させた試料のミクロ組織 試料の大きさ：直径 $125 \mathrm{~mm}$, 高さ $140 \mathrm{~mm}$

を利用してるつぼ底に沈積させ，上澄みのみ注湯することに より，溶製した合金の耐食性を改善している ${ }^{94) ~ 98) 。 P i d g e o n ~}$ 法などで製錬された高純度のマグネシウムを用いれば，Mn 添加量は少なくて済むが，高コストである。一方，低コス卜 の電解マグネシウムは純度が低く, 数百 $\mathrm{ppm}$ 程度の Fe を含 むため，これを除去するための Mn 添加量む多くする必要が ある。この場合, 数十 $\mu \mathrm{m}$ の粗大な Al-Mn 化合物が残留し, 展伸性や表面処理性に悪影響を及ぼすこと屯想定される。こ のことは, 将来のマグネシウム合金部材の適用増加に伴って 発生するスクラップ材をリサイクルする場合においても同様 で，鉄くず等から混入する $\mathrm{Fe}$ を除去する必要がある。した がって，低コストの地金を用いて高品質なマグネシウム合金 を製造する手法を開発することにより，リサイクルプロセス
への応用展開も可能となる。そこで, 著者らは, $300 \mathrm{ppm}$ 以 上の多量の $\mathrm{Fe}$ を含む電解マグネシウムを用いて, 残留 $\mathrm{Fe} や$ 粗大な Al-Mn 化合物の少ない, 高品質な AZ31 マグネシウム 合金鋳塊を作製することを目的として，Mn 添加量，Fe 除去 のために溶湯鎮静温度および鎮静時間を変化させて鎮静し, 晶出する $\mathrm{Al}-\mathrm{Mn}$ 系化合物の大きさと分布状況, 残留する $\mathrm{Fe}$ および Mn 量, および耐食性を評価した。なお，用いた溶湯 のサイズは直径 $125 \mathrm{~mm}$ ，高さ $140 \mathrm{~mm}$ である。

$\mathrm{Mn}$ 添加量を $0.3 \%, 0.5 \%, 0.8 \%, 1.4 \%$ と変化させた $\mathrm{Mg}$ $3 \% \mathrm{Al}-1 \% \mathrm{Zn}$ 合金溶湯を $650^{\circ} \mathrm{C}$ で $20 \mathrm{~min}$ 鎮静した場合のミク 口組織を図 44 に示す。すべての合金とも, $650^{\circ} \mathrm{C}-20 \mathrm{~min}$ の鎮 静により, 化合物の大半は試料底部に沈降する。これらの化 合物は底部から $5 \mathrm{~mm}$ の高さまで堆積するものの, その堆積 


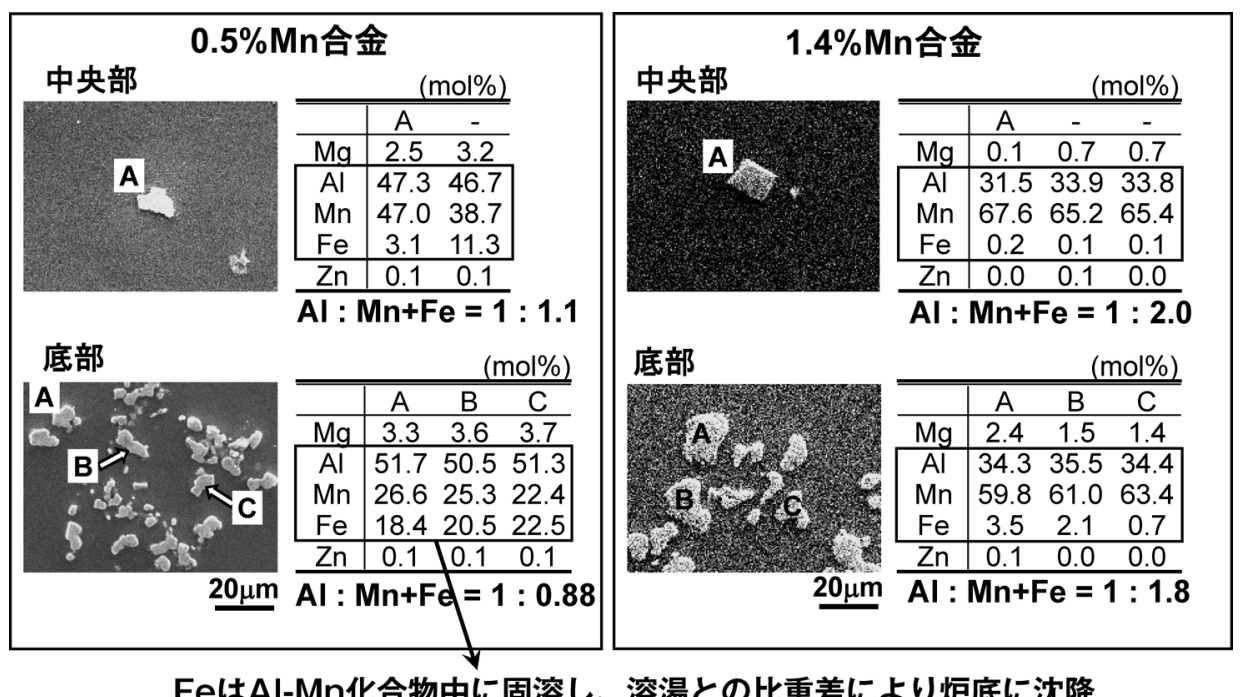

FeはAI-Mn化合物中に固溶し、溶湯との比重差により炉底に沈降

図 $45 \mathrm{Mg}-3 \mathrm{Al}-1 \mathrm{Zn}(\mathrm{mass} \%)$ 合金溶湯を $650^{\circ} \mathrm{C}$ で $20 \mathrm{~min}$ 鎮静した試料中で観察される化合物の WDX 組成分析結果

高さは $1.4 \% \mathrm{Mn}$ 合金より低い。底部の化合物粒径は, Mn 添 加量の増加とともに大きくなる。また， $0.8 \%$ 以上 $\mathrm{Mn}$ を添加 した場合，試料中央部抢よび上部でも $10 \mu \mathrm{m}$ 以上の粗大な化 合物も存在する。

$0.5 \%$ および $1.4 \% \mathrm{Mn}$ 添加合金の試料中央部㧍よび底部で 観察された Al-Mn 化合物を波長分散型 X 線マイクロアナラ イザ（WDX）により定量分析した結果を図 45 に示す。底部 の化合物中の $\mathrm{Fe}$ 固溶量は， $0.5 \% \mathrm{Mn}$ 添加合金の方が， $1.4 \%$ $M n$ 添加合金より多い。このことは，前者では鎮静中に，少 数の化合物に約 $20 \mathrm{~mol} \%$ もの多くの Fe が固溶し, 後者では 多くの化合物に $2 \sim 3 \mathrm{~mol} \%$ と少量の Fe が固溶し, 沈積する ことを示している。1.4\% Mn 合金の中央部で観察される化合 物中には $\mathrm{Fe}$ の固溶はほとんどないが，0.5\% Mn 合金の中央 部では, $\mathrm{Fe}$ を $11 \mathrm{~mol} \%$ 含有する化合物む存在する。また, 各 化合物の $\mathrm{Al}: \mathrm{Mn}+\mathrm{Fe}$ 比は，0.5\% Mn 合金では約 1:1, $1.4 \% \mathrm{Mn}$ 合金では $1: 2$ 之, 本検討合金中で観察される化合物は, 従来 AZ91D 合金などで報告されている $\mathrm{Al}_{6} \mathrm{Mn}, \mathrm{Al}_{4} \mathrm{Mn} や \mathrm{Al}_{8} \mathrm{Mn}_{5}$ と は異なる。Al-Mn 系二元状態図 ${ }^{99,100)}$ と WDX 組成分析結果 から本検討合金の化合物を類推すると， $0.5 \% \mathrm{Mn}$ 合金では $\gamma_{2}$ 相, $1.4 \% \mathrm{Mn}$ 合金では $\beta \mathrm{Mn}$ が晶出しているあのと考えられ る。また底部では, これらの化合物中に Fe が置換固溶した 化合物が沈積するむのと考えられる。

$\mathrm{Mn}$ 添加量を変化させ, $650^{\circ} \mathrm{C}$ で $20 \mathrm{~min}$ 鎮静した試料の上 部, 中部拉よびるつぼ底近傍の ICP 発光分光分析により組成 分析した結果を表 2 に示す。 $\mathrm{Mn}$ 添加量の増加に伴い, 残留 $\mathrm{Mn}$ 量は増加し, $\mathrm{Fe}$ 量は減少する。 $0.5 \%$ 以上の $\mathrm{Mn}$ を添加し た試料の上部抢よび中央部の $\mathrm{Fe}$ 量は, いずれも $30 \mathrm{ppm}$ 以下 であるが， $0.3 \% \mathrm{Mn}$ 添加試料では, 試料上部扔よび中央部に それぞれ $67 \mathrm{ppm}$ および $72 \mathrm{ppm}$ の $\mathrm{Fe}$ が残留する。前述したよ うに Mn 添加量の少ない試料では, 少数の Al-Mn 化合物中に 大量の Fe が固溶するものの, Mn 添加量が少ないため, Al-Mn 化合物が Fe を固溶しきれず，溶融マグネシウム中に 残留する $\mathrm{Fe}$ が多くなるものと考えられる。一方， $0.3 \% \mathrm{Mn}$ 添 加合金では, Al-Mn 化合物中の $\mathrm{Fe}$ 量が多く, また, 化合物 そのあのあ小さいため沈降しにくく, Fe を多量に固溶した $\mathrm{Al}-\mathrm{Mn}$ 化合物が上部, 中央部に残留し, その結果 $\mathrm{Fe}$ 量が多
表 $2 \mathrm{Mg}-3 \mathrm{Al}-1 \mathrm{Zn}(\operatorname{mass} \%)$ 合金溶湯を $650^{\circ} \mathrm{C}$ で $20 \mathrm{~min}$ 鎮静した試料の化学組成

$(\operatorname{mass} \%)$

\begin{tabular}{|c|c|c|c|c|c|}
\hline 合金 & 分析位置 & $\mathrm{Al}$ & $\mathrm{Zn}$ & Mn & $\mathrm{Fe}$ \\
\hline \multirow{3}{*}{$0.3 \% \mathrm{Mn}$} & 上 部 & 4.1 & 1.0 & 0.26 & 0.0067 \\
\hline & 中央部 & 4.1 & 0.9 & 0.25 & 0.0072 \\
\hline & 底 部 & 4.6 & 1.2 & 0.91 & 0.1493 \\
\hline \multirow{3}{*}{$0.5 \% \mathrm{Mn}$} & 上 部 & 3.6 & 0.9 & 0.36 & 0.0029 \\
\hline & 中央部 & 3.2 & 1.1 & 0.41 & 0.0030 \\
\hline & 底 部 & 6.5 & 0.9 & 3.39 & 0.2379 \\
\hline \multirow{3}{*}{$0.8 \% \mathrm{Mn}$} & 上 部 & 3.3 & 1.3 & 0.43 & 0.0009 \\
\hline & 中央部 & 3.1 & 1.2 & 0.52 & 0.0015 \\
\hline & 底 部 & 5.0 & 1.4 & 5.22 & 0.7159 \\
\hline \multirow{3}{*}{$1.4 \% \mathrm{Mn}$} & 上 部 & 3.1 & 1.0 & 0.61 & 0.0023 \\
\hline & 中央部 & 3.4 & 1.2 & 0.52 & 0.0005 \\
\hline & 底 部 & 8.3 & 0.8 & 11.3 & 0.3442 \\
\hline
\end{tabular}

\section{くなることも考えられる。}

各試料の上部打よび中央部から採取した試料の $5 \% \mathrm{NaCl}$ 溶 液中への浸漬試験結果を図 46 に示す。 $0.3 \% \mathrm{Mn}$ 添加合金で は, 表 2 に示すように $\mathrm{Fe}$ が多く残留するため, 耐食性は著 しく劣る。 $0.5 \% \mathrm{Mn}$ 添加合金では, Fe 量は $30 \mathrm{ppm}$ 程度で, 上部の耐食性は市販材とほぼ同等であるが, 中央部では劣 る。 $650^{\circ} \mathrm{C}-20 \mathrm{~min}$ の鎮静条件で市販材と同等の耐食性を得る ためには，0.8\% 以上の Mn 添加が必要である。 Lunder ${ }^{101) ~ 103) ~}$ らは $5 \% \mathrm{NaCl}$ 水溶液中における $\mathrm{Al}_{\mathrm{x}} \mathrm{Mn}_{\mathrm{y}}$ 系化合物のカソード 電流密度を測定し, $\mathrm{Al}_{\mathrm{x}}(\mathrm{Mn}, \mathrm{Fe})_{\mathrm{y}}$ の $\mathrm{x} / \mathrm{y}$ 比が小さいほど, ま た, Mn に置換する Fe 量が多くなるほどカソード電流密度が 大きくなり，耐食性を劣化させることを報告している。図 45 に示したように，0.5\% Mn 合金の中央部に存在する化合物の $\mathrm{Al} / \mathrm{Mn}+\mathrm{Fe}$ 比はほぼ 1 で, $1.4 \% \mathrm{Mn}$ 合金のそれより大きいが, $0.5 \% \mathrm{Mn}$ では置換固溶する $\mathrm{Fe}$ が $1.4 \% \mathrm{Mn}$ 合金より多いため, この影響により耐食性が低下するものと考えられる。した がって, 鎮静時間を延長し, $20 \mathrm{~min}$ の鎮静で沈降させ得な 


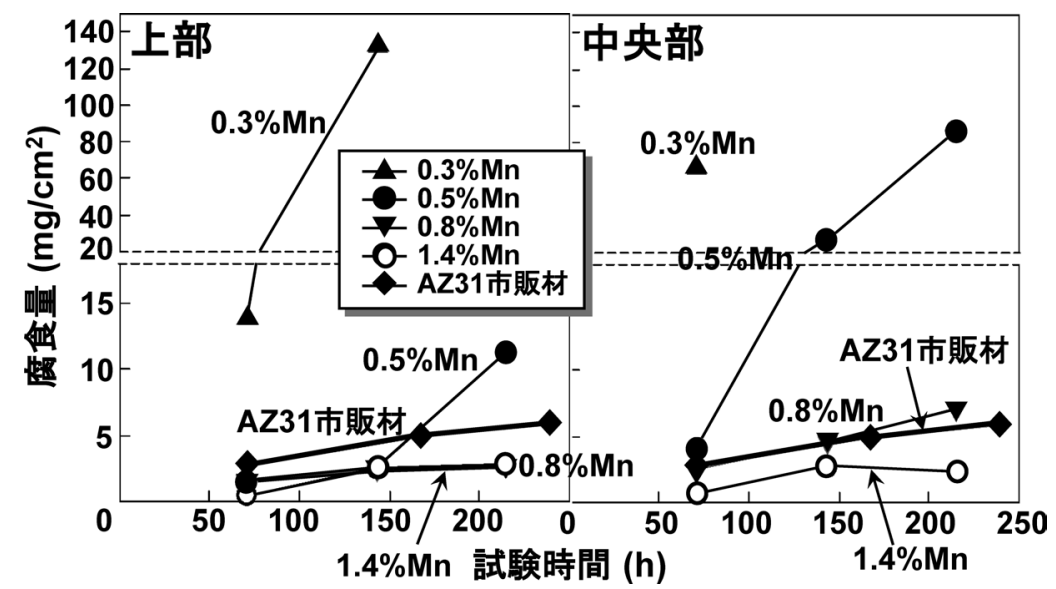

図 $46 \mathrm{Mg}-3 \mathrm{Al}-1 \mathrm{Zn}\left(\operatorname{mass} \%\right.$ ) 合金溶湯を $650^{\circ} \mathrm{C}$ で $20 \mathrm{~min}$ 鎮静した試料の而食性

\section{$20 \mathrm{~min}$ 鎮静}

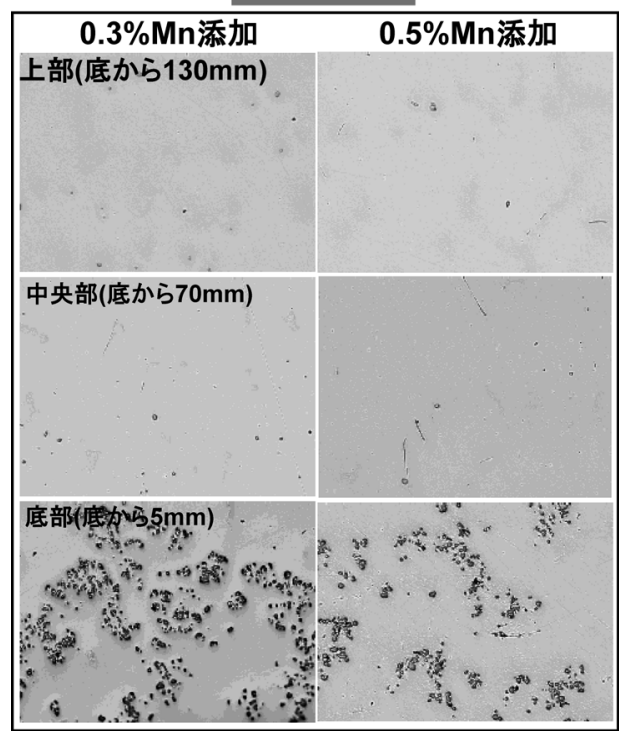

\section{0min 鎮静}

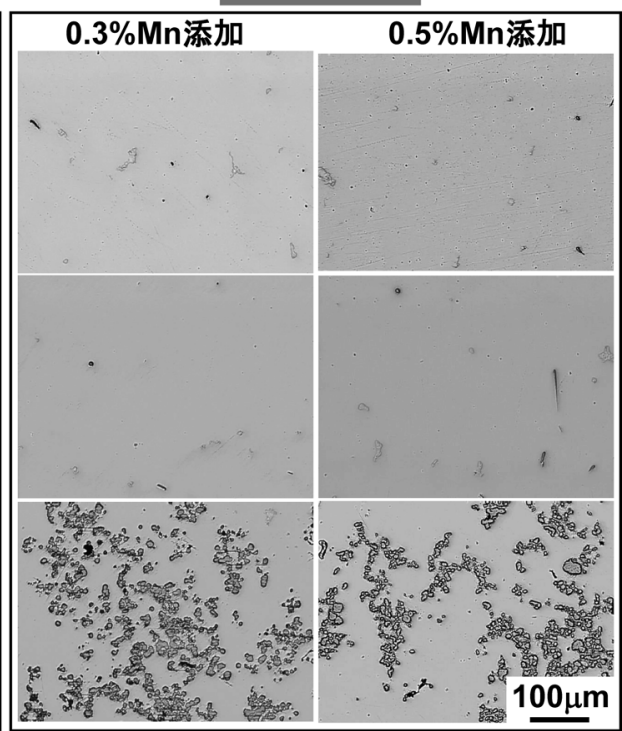

図 $47 \mathrm{Mg}-3 \mathrm{Al}-1 \mathrm{Zn}(\operatorname{mass} \%)$ 合金溶湯を $650^{\circ} \mathrm{C}$ で $20 \mathrm{~min}$ および $120 \mathrm{~min}$ 鎮静した試料のミクロ組織

かった Fe を含む Al-Mn 化合物をある程度沈降させれば，耐 食性を改善できるむのと考えられる。図 45 に示すような，中 央部の $5 \mu \mathrm{m}$ 程度の化合物をるつぼ底部までの沈降させるた めに必要な時間を，化合物とマグネシウム溶湯の比重差およ び化合物の大きさを用いてストークスの式から計算すると, $120 \mathrm{~min}$ となる。この計算結果をもとに， $0.3 \%$ および $0.5 \%$ $\mathrm{Mn}$ 添加試料を $650^{\circ} \mathrm{C}$ で $120 \mathrm{~min}$ 鎮静し，化合物の挙動につい て調べた。その結果を $20 \mathrm{~min}$ 鎮静試料と比較して図 47 に示 す。両合金とも底部の化合物量は $120 \mathrm{~min}$ 鎮静試料の方が多 く，また上部执よび中央部には粗大な $\mathrm{Al}-\mathrm{Mn}$ 化合物はほとん ど観察されない。このことは，120 min の鎮静により $\mathrm{Al}-\mathrm{Mn}$ 化合物の沈降が充分に行われていることを示す。Al-Mn 化合 物の組成をWDX で調べたが，鎮静時間が変化しても化合物 組成に大きな変化は認められていない。

$0.3 \%$ および $0.5 \% \mathrm{Mn}$ 添加合金を $650^{\circ} \mathrm{C}$ で $120 \mathrm{~min}$ 鎮静した 試料の上部，中部㧍よびるつぼ底近傍の合金組成を表 3 に示 す。 $120 \mathrm{~min}$ の鎮静により， $0.3 \%$ および $0.5 \%$ 添加試料とも $\mathrm{Fe}$ 量を $30 \mathrm{ppm}$ 以下にまで減少させることができる。表 2 に 示した $20 \mathrm{~min}$ 鎮静した試料と比較すると, 特に $0.3 \% \mathrm{Mn}$ 添
表 $3 \mathrm{Mg}-3 \mathrm{Al}-1 \mathrm{Zn}(\operatorname{mass} \%)$ 合金溶湯を $650^{\circ} \mathrm{C}$ で 120 min 鎮静した試料の化学組成

$(\operatorname{mass} \%)$

\begin{tabular}{c|c|c|c|c|c}
\hline \hline 合金 & 分析位置 & $\mathrm{Al}$ & $\mathrm{Zn}$ & $\mathrm{Mn}$ & $\mathrm{Fe}$ \\
\hline \multirow{3}{*}{$0.3 \% \mathrm{Mn}$} & 上 部 & 3.9 & 1.1 & $\mathbf{0 . 3 2}$ & $\mathbf{0 . 0 0 2 5}$ \\
& 中央部 & 3.8 & 1.0 & $\mathbf{0 . 3 2}$ & $\mathbf{0 . 0 0 2 6}$ \\
& 底 部 & $\mathbf{4 . 4}$ & $\mathbf{1 . 2}$ & $\mathbf{0 . 8 9}$ & $\mathbf{0 . 5 4 7 0}$ \\
\hline \multirow{3}{*}{$0.5 \% \mathrm{Mn}$} & 上 部 & 3.6 & 1.1 & $\mathbf{0 . 4 7}$ & $\mathbf{0 . 0 0 2 9}$ \\
& 中央部 & 3.5 & 1.0 & $\mathbf{0 . 4 8}$ & $\mathbf{0 . 0 0 1 7}$ \\
& 底 部 & $\mathbf{4 . 7}$ & $\mathbf{1 . 1}$ & $\mathbf{1 . 7 3}$ & $\mathbf{0 . 5 7 0 0}$ \\
\end{tabular}

加試料ではその Fe 量低減効果が顕著である。逆に, 合金中 の Mn 量は添加 $\mathrm{Mn}$ 量とともに増加し, また $120 \mathrm{~min}$ の鎮静に より $\mathrm{Mn}$ 量が若干増加する。

$0.3 \%$ および $0.5 \% \mathrm{Mn}$ 添加合金を $650^{\circ} \mathrm{C}$ で $20 \mathrm{~min}$ および $120 \mathrm{~min}$ 鎮静した試料の浸漬試験結果を図 48 に示す。両合金 とも，120 min 鎮静することにより，耐食性は向上する。特 


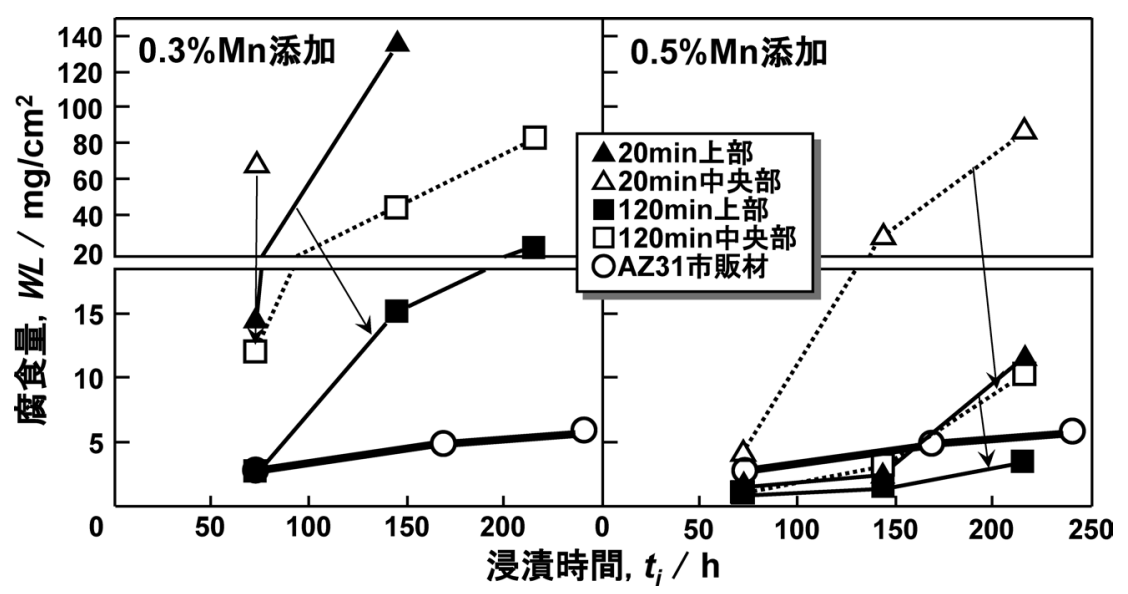

図 $48 \mathrm{Mg}-3 \mathrm{Al}-1 \mathrm{Zn}(\operatorname{mass} \%)$ 合金溶湯を $650^{\circ} \mathrm{C}$ で $120 \mathrm{~min}$ 鎮静した試料の耐食性

に $0.5 \% \mathrm{Mn}$ 合金では市販材と同等かそれ以上の耐食性が得ら れる。これは, $120 \mathrm{~min}$ の鎮静により $\mathrm{Fe}$ を含む $\mathrm{Al}-\mathrm{Mn}$ 化合物 数が減少するためと考えられる。このように，0.5\% Mn 添加 合金を $650^{\circ} \mathrm{C}$ で $120 \mathrm{~min}$ 鎮静することにより，市販材並みの 充分な耐食性を持ち, 晶出する化合物量むほとんどが $10 \mu \mathrm{m}$ 以下という高品質な AZ31 鋳塊を，電解マグネシウムを用い て溶製することができた。ただし，0.3\% Mn 添加合金の $120 \mathrm{~min}$ 鎮静試料および $0.5 \% \mathrm{Mn}$ 添加合金の $20 \mathrm{~min}$ 鎮静試料 の中央部では, $\mathrm{Fe}$ 量は $30 \mathrm{ppm}$ 以下でも耐食性に劣る。この 原因を明らかにするためには, 今後, 化合物の種類, および 腐食形態との関係を詳細に調べる必要がある。

以上のような Al-Mn 母合金添加と鎮静の組合せによる不 純物除去に関する研究では, 以下のような成果が得られた。

- $\mathrm{Mn}$ 添加量 $0.8 \%$ 以上の試料では, $650^{\circ} \mathrm{C}-20 \mathrm{~min}$ の鎮静 で Fe を十分に除去できるあのの, 晶出する化合物の粒径が $10 \mu \mathrm{m}$ 以上のものが多く, 残留 $\mathrm{Mn}$ 量も多い。

- $650^{\circ} \mathrm{C}$ で $120 \mathrm{~min}$ 鎮静することにより, 0.5\% Mn 添加合 金でも Fe 量は $30 \mathrm{ppm}$ 以下となり, 市販材並みの耐食性が得 られるようになる。また，残留する Mn 化合物は少なく，高 品質な合金の溶製が可能となる。

3.4.2 Al-Mn 添加 + 撹拌 + フィルタによる効率的な溶湯 清浄化

$300 \mathrm{ppm}$ 以上の Fe を含む電解マグネシウムを用いて AZ31

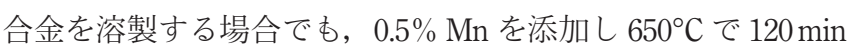
鎮静することにより, 残留 $\mathrm{Fe}$ 量を $30 \mathrm{ppm}$ 以下にでき, 市販 材並みの耐食性まで改善できる。しかし，120 min の鎮静は 工業的にはコスト高を招く。そこで, 溶湯処理時間の短縮に よる溶湯清浄化プロセスの効率化を目的として, 合金溶製時 にロッドを挿入し, 回転による遠心力および化合物トラップ としてのフィルタの設置による簡便な操作により化合物除去 を行った。短時間の溶湯処理を用いて溶製した合金について, 化合物の分布や大きさ, 残留 Fe および Mn 量, さらには耐食 性を調べ，清浄度評価を行った。

水を用いて本実験の条件を模擬した場合の溶湯の流れを図 49 に示す。溶湯は大きな 2 つ流れに沿って移動する。一つ は回転による遠心力によりるつぼ壁に沿って流れ, るつぼ底 まで達した後, 最終的にロッド下端に戻ってくる。一方, る つぼ壁を通り，るつぼ底まで達しないで，ロッド下端に戻っ てくる流れあ存在する。そのため, AZ31 合金に Al-Mn 母合
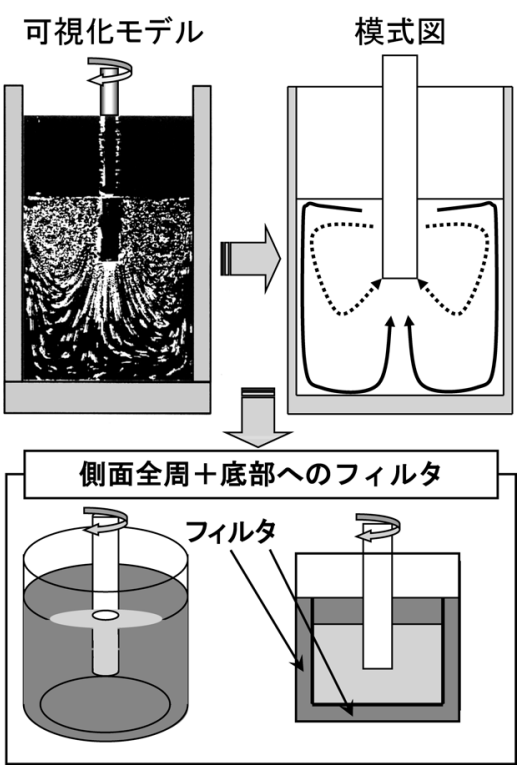

図 49 ロッドを用いた撹拌により溶湯中に生じる流れ と, それを考慮したフィル夕設置

金を添加し， Al-Mn 系化合物が溶湯中を浮遊しているような 場合, ロッドによる回転から生じる遠心力とマグネシウム合 金溶湯と Al-Mn 系化合物の比重差により, るつぼ壁面に移 動した Al-Mn 系化合物は, 速度の大きなロッド近傍の流れ に引き寄せられ, その結果, インゴット中心付近に粗大な化 合物が集中するようになる。そこで, るつぼ側壁およびるつ ぼ底部に化合物のトラップ用フィルタとしてアルミナファイ バブランケットを配置し, $180 \mathrm{rpm}$ の速度で $3 \mathrm{~min}$ の擋拌を施 し，その不純物削減効果を調べた。

表 4 に $0.8 \% \mathrm{Mn}$ を添加し, $3 \mathrm{~min}$ 鎮静のみ, ロッド撹拌の み, および側面およびるつぼ底部にフィルタを用いてロッド 擋拌した試料の中央部における組成分析結果を示す。 $3 \mathrm{~min}$ 鎮静のみでは, 試料底部のいずれの位置でも Feが多量に含 まれるが, 試料中間位置および中央部に残留する $\mathrm{Fe}$ 量は 52 5 $5 \mathrm{ppm}$ と, ASTM 規格值の $50 \mathrm{ppm}$ を超える部分も存在 する。ロッド擋找試料でも, 中心位置および中間部では $50 \mathrm{ppm}$ 以上 $\mathrm{Fe}$ が残留する。特に試料中心位置では $98 \mathrm{ppm}$ と, $3 \mathrm{~min}$ 鎮静試料よりも高い值を示すとともに, Mn 量む $1.37 \%$ と高く, Fe を含む Al-Mn 化合物の集積が顕著である。 
表 4 Mg-3Al-1Zn (mass\%) 合金に 0.8 mass \% Mn を添加した試料の試料中央部の化学組成 (mass \%)

\begin{tabular}{c|c|c|c|c|c}
\hline \hline フィルタ設置条件 & 分析位置 & $\mathrm{Al}$ & $\mathrm{Zn}$ & $\mathrm{Mn}$ & $\mathrm{Fe}$ \\
\hline \multirow{3}{*}{$3 \mathrm{~min}$ 鎮静のみ } & 外 側 & 3.2 & 1.3 & 0.72 & 0.0047 \\
& 中間部 & 3.2 & 1.3 & 0.87 & $\mathbf{0 . 0 0 5 2}$ \\
& 中 心 & 3.3 & 1.3 & 1.04 & $\mathbf{0 . 0 0 5 5}$ \\
\hline \multirow{3}{*}{ 擋拌のみ } & 外 側 & 3.1 & 1.3 & 0.63 & 0.0029 \\
& 中間部 & 2.7 & 1.2 & 0.80 & $\mathbf{0 . 0 0 5 0}$ \\
& 中 心 & 2.7 & 1.1 & 1.37 & $\mathbf{0 . 0 0 9 8}$ \\
\hline \multirow{3}{*}{ 側面全周 + 底部 } & 中外 & 3.1 & 0.9 & $\mathbf{0 . 4 6}$ & $\mathbf{0 . 0 0 3 1}$ \\
& 中間部 & 3.0 & 0.8 & $\mathbf{0 . 4 6}$ & $\mathbf{0 . 0 0 3 3}$ \\
& 中 心 & 2.9 & 0.9 & $\mathbf{0 . 5 4}$ & $\mathbf{0 . 0 0 3 9}$ \\
& フィタ部 & 3.8 & 1.1 & 0.61 & $\mathbf{0 . 0 1 1 7}$ \\
\hline
\end{tabular}

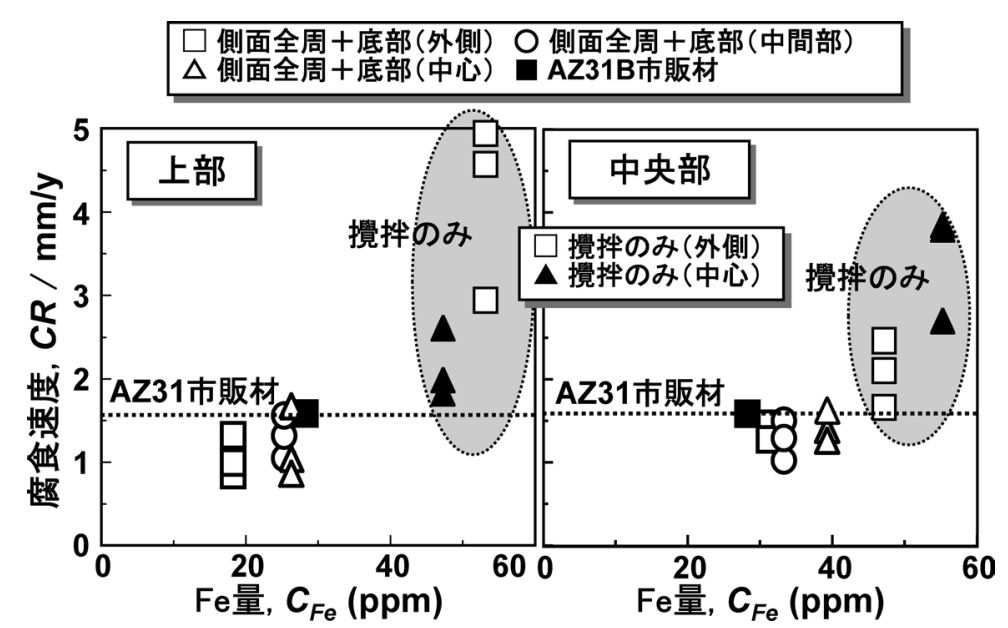

図 50 残留 $\mathrm{Fe}$ 量と腐食速度の関係

試料中央部の外側では Fe 量が $29 \mathrm{ppm}$ まで減少することから, このようなインゴット中心部における化合物の集積は, 図 49 に示した溶湯の流れにより，中心に向かって Fe を含む化合 物が引き寄せられるためと考えられる。側面と底部にフィル 夕を用いた試料は，ロッド撹拌のみの試料と同様，インゴッ 卜中心で残留する $\mathrm{Fe}$ 量が増加する傾向がみられるむのの, Fe 量は 31 39ppmで，いずれの位置においてもASTM 規格值 より充分低い。しかもフィル夕を用いない他の試料に比べ, $\mathrm{Mn}$ 量は減少する。また，フィル夕部には，Feが多量に含ま れるが，Feを含む Al-Mn 化合物がフィルタにトラップされ た結果と考えられる。

各鋳塊の試料上部および中央部における塩水浸漬試験結果 を図 50 に示す。長時間鎮静のみの試料の上部から採取した 試料は浸漬時間の経過に伴う腐食速度の増加が小さく, 腐食 速度は両試料とも $1 \mathrm{~mm} / \mathrm{y}$ 以下のほぼ一定で, 非常に良好な 耐食性を示す。これは, 溶湯の鎮静により試料上部では $\mathrm{Fe}$ を含む化合物が沈降を完了し，ほとんど残留しないためと考 えられる。ロッドおよびフィル夕を用いて溶製した試料は AZ31B 市販材と同等以上の耐食性を示すむのの, 腐食速度は 1.1 1.6 mm/y と, 試料上部では両鎮静試料より耐食性が若干 劣る。しかし, 試料中央部では, 同程度の耐食性を示し, 市 販材より優れる。このように，試料中央部では $3 \mathrm{~min}$ 間の ロッド回転およびフィル夕位置の最適化により鎮静試料並み
の耐食性を得ることが可能となる。

以上のように，側面および底部にフィル夕を設置し，溶湯 清浄化を図った試料では, 試料中心付近の化合物量は顕著に 少なくなる。試料上部の残留 $\mathrm{Fe}$ 量は $30 \mathrm{ppm}$ 未満にまで減少 し，底部にもフィル夕を設置することにより，Mn 量む少な くなる。その結果，耐食性も AZ31B 市販材之同等かそれ以 上にまで向上し，短時間の溶湯処理でも ASTM 規格を満足 し，市販材並みの耐食性を示す鋳塊の作製が可能となった。

\section{4.おわりに}

本稿では, 長岡技術科学大学赴任後に進めてきた研究内容 をまとめた。長年，マグネシウム合金に関する研究を行って きたが，未だに素性のわからない点あある。逆にそのような 点が興味を引く点である。本稿が，少しであ若い研究者らの 興味を引き, マグネシウムの研究者が増えることを期待した い。最後になるが, これまで研究生活を充実できたのも, 長 岡技術科学大学 機械系 鎌土重晴教授を始め, 関係各位から の惜しみない助けによるところが大いにある。衷心より感謝 を申上げたい。

\section{参 考 文 献}

1）上杉徳照, 東 健司 : “第一原理シミュレーションによる添加 元素の最適化設計”，軽金属，54 (2004), 82-89.

2) M. Suzuki, H. Sato, K. Maruyama and H. Oikawa: "Creep behavior 
and deformation microstructures of $\mathrm{Mg}-\mathrm{Y}$ alloys at $550 \mathrm{~K}$, Mater. Sci. Eng., A252 (1998), 248-255.

3) J. Koike, T. Kobayashi, T. Mukai, H. Watanabe, M. Suzuki, K. Maruyama and K. Higashi: "The Activity of Non-basal Slip Systems and Dynamic Recovery at Room Temperature in Fine-Grained AZ31B Magnesium Alloys", Acta Mater., 51 (2003), 2055-2065.

4）小林孝幸，小池淳一，吉田 雄，鎌土重晴，鈴木真由美，丸 山公一，小島 陽：“AZ31 マグネシゥム合金での活動すべり 系の粒径依存性”, 日本金属学会誌, 67 (2003), 149-152.

5) J. Koike, R. Ohyama, T. Kobayashi, M. Suzuki and K. Maruyama: "Grain-Boundary Sliding in AZ31 Magnesium Alloys at Room Temperature to 523 K”, Mater. Trans., 44 (2003), 445-451.

6) E. Abe, Y. Kawamura, K. Hayashi and A. Inoue: "Long-Period Ordered Structure in a High-Strength Nanocrystalline Mg-1at $\% \mathrm{Zn}-$ $2 a t \%$ Y Alloy Studied by Atomic-Resolution Z-Contrast STEM", Acta Metall. et Mater., 50 (2002), 3845-3857.

7) D. H. Ping, K. Hono, Y. Kawamura and A. Inoue: "Local Chemistry of a Nanocrystalline High-Strength $\mathrm{Mg}_{97} \mathrm{Y}_{2} \mathrm{Zn}_{1}$ Alloy", Phil. Mag. Lett., 82 (2002), 543-551.

8) A. Inoue, M. Matsushita, Y. Kawamura, K. Amiya, K. Hayashi and J. Koike: "Novel Hexagonal Structure of Ultra-High Strength Magnesium-Based Alloys", Mater. Trans., 43 (2002), 580-584.

9) Y. Kawamura, K. Hayashi, A. Inoue and T. Masumoto: "Rapidly Solidified Powder Metallurgy $\mathrm{Mg}_{97} \mathrm{Zn}_{1} \mathrm{Y}_{2}$ Alloys with Excellent Tensile Yield Strength above $600 \mathrm{MPa}$, Mater. Trans., 42 (2001), 1172-1176.

10) K. Mori, Z. Kang, J. Oravec, and Y. Oishi: "Corrosion Resistance of Polymer-plated Magnesium Alloys", Mater. Sci. Forum, 419-422 (2003), 889-896.

11) K. Mori, Z. Kang, J. Oravec and Y. Oishi: "Direct Adhesion of PPS to Polymer-Plated Magnesium Alloys", Mater. Sci. Forum, 419-422 (2003), 921-926.

12）山本厚之, 渡邊 淳, 福本信次, 菅原加名, 椿野晴繁: “マグ ネシウム蒸着法によるマグネシウム合金の表面改質”，軽金属， 50 (2000), 619-620.

13) A. Yamamoto, A. Watanabe, K. Sugahara, H. Tsubakino and S. Fukumoto: "Improvement of corrosion resistance of magnesium alloys by vapor deposition", Scripta Mater., 44 (2001), 1039-1042.

14) A. Yamamoto, A. Watanabe, K. Sugahara, S. Fukumoto and H. Tsubakino: "Deposition coating of magnesium alloys with pure magnesium", Mater. Trans., 42 (2001), 1237-1242.

15) Y. Chino, A. Yamamoto, H. Iwasaki, M. Mabuchi and H. Tsubakino: "Solid recycling of an AZ31 Mg alloy with a vapor deposition coating layer of high purity Mg", Mater. Trans., 44 (2003), 578-582.

16) K. Kondoh, H. Oginuma, R. Tuzuki and T. Aizawa: "Magnesium matrix composite with solid-state synthesized $\mathrm{Mg}_{2} \mathrm{Si}$ dispersoids", Mater. Trans., 44 (2003), 611-618.

17) T. Motegi, E. Yano, N. Wada and Y. Tamura: "Continuous Casting of Semisolid Mg-Al-Zn Alloy”, Mater. Sci. Forum, 419-422 (2003), 605-610.

18）矢野英治，和田典也，西川直樹，茂木徹一：“傾斜冷却板を用 いた AZ91D マグネシウム合金の半溶融鋳造”，日本金属学会 誌, 66 (2002), 1131-1134.

19） R. S. Rudi, S. Kamado, N. Ikeya, T. Araki and Y. Kojima: "High temperature strength of semi-solid formed $\mathrm{Mg}-\mathrm{Zn}-\mathrm{Al}-\mathrm{Ca}$ alloys", Mater. Sci. Forum, 350-351 (2000), 79-84.

20） S. Kamado, N. Ikeya, R. S. Rudi, T. Araki and Y. Kojima: "Application of semi-solid forming to $\mathrm{Mg}-\mathrm{Zn}-\mathrm{Al}-\mathrm{Ca}$ alloys", Mater. Sci. Forum, 350-351 (2000), 205-213.

21) T. Takenaka, S. Isazawa, M. Mishina, Y. Kamo and M. Kawakami: "Electrorefining of Magnesium in Molten Salt and Its Application for Recycling", Mater. Trans., 44 (2003), 546-551.

22）竹中俊英, 川上正博, 仲 勇介：“希土類金属を含むマグネシ ウム合金の製造方法”，特願 2003-111642.

23）鎌土重晴, 岩澤 秀, 大内清明, 小島 陽, 二宮隆二： “Mg-Gd 系㧍よび Mg-Tb 系合金の時効硬化特性抢よび高温強 度”，軽金属，42 (1992)，727-733.

24）岩澤 秀, 根岸祐司, 鎌土重晴, 小島 陽, 二宮隆二： “Mg-Gd 系および Mg-Dy 系合金の時効硬化特性および高温引
張特性”，軽金属，44 (1994), 3-8.

25）根岸祐司，岩澤 秀，鎌土重晴，小島 陽，二宮隆二： “ $\mathrm{Mg}-10 \mathrm{mass} \% \mathrm{Gd}$ 系扔よび $\mathrm{Mg}-10 \mathrm{mass} \% \mathrm{Dy}$ 系合金の時効特性 之高温引張特性に及ぼす Y, Nd 添加の影響”, 軽金属, 44 (1994), 549-554.

26）根岸祐司, 西村卓寛, 岩澤 秀, 鎌土重晴, 小島 陽, 二宮 隆二 : “Mg-Gd-Nd-Zr 抢よび $\mathrm{Mg}-\mathrm{Dy}-\mathrm{Nd}-\mathrm{Zr}$ 合金の時効特性抢 よび引張特性”，軽金属，44 (1994)，555-561。

27）根岸祐司, 西村卓寛, 桐生雅夫, 鎌土重晴, 小島 陽, 二宮 隆二： " $\mathrm{Mg}$ - 重希土類元素 (Gd, Dy)-Nd 系合金の $\mathrm{Mg}$ リッチ 側の状態図，時効特性および引張特性”，軽金属，45 (1995), $57-63$.

28) S. Kamado and Y. Kojima: "Ageing characteristics and high temperature tensile properties of magnesium alloys containing heavy rare earth elements", Proc. of 3rd Intern. Magnesium Conf., ed. by G. W. Lorimer, The Institute of Materials, Manchester, UK, (1997), 327342.

29）桐生雅夫，奥村勇人，鎌土重晴，小島 陽，二宮隆二，中津 川勲：“重希土類元素を含む耐熱マグネシウム合金の耐食性”, 軽金属, 46 (1996), 39-44.

30）谷池茂弘, 北口 豊, 鎌土重晴, 小島 陽, 関伊佐夫, 久保 田耕平：“マグネシウム - 重希土類元素合金の鍛造性および鍛 造材の時効特性と引張特性”, 軽金属, 47 (1997), 261-266.

31） I. Nakatsugawa, S. Kamado, Y. Kojima, R. Ninomiya and K. Kubota: "Corrosion of magnesium alloys containing rare earth elements", Corrosion Reviews, 16 (1998), 139-157.

32) I. A. Anyanwu, S. Kamado and Y. Kojima: "Aging Characteristics and Tensile Properties of Mg-Gd-Y-Zr Alloys", Mater. Trans., 42 (2001), 1206-1211.

33) I. A. Anyanwu, S. Kamado and Y. Kojima: "Creep Properties of Mg-Gd-Y-Zr Alloys”, Mater. Trans., 42 (2001), 1212-1218.

34） T. Kawabata, K. Matsuda, S. Kamado, Y. Kojima, S. Ikeno: "HRTEM Observation of the Precipitates in Mg-Gd-Y-Zr Alloy”, Mater. Sci. Forum, 419-422 (2003), 303-306.

35) T. Honma, T. Ohkubo, K. Hono and S. Kamado: "Chemistry of nanoscale precipitates in $\mathrm{Mg}-2.1 \mathrm{Gd}-0.6 \mathrm{Y}-0.2 \mathrm{Zr}$ (at.\%) alloy investigated by the atom probe technique", Mater. Sci. and Eng. A, A395 (2005), 301-306.

36）川畑常眞, 松田健二, 鎌土重晴, 小島 陽, 池野 進：“ $\mathrm{Mg}$ $12.0 \% \mathrm{Gd}-1.9 \% \mathrm{Y}-0.7 \% \mathrm{Zr}$ 合金に打ける時効析出物の高分解能透 過型電子顕微鏡観察”, 日本金属学会誌, 70 (2006), 828-834.

37) T. Kawabata, Y. Fukuda, K. Matsuda, S. Kamado, Y. Kojima, S. Ikeno: "HRTEM Observation of the Precipitates in Heat-Resistant Mg-Gd-Y-Zr Alloy", Mater. Sci. Forum, 539-543 ( 2007), 17691774.

38） T. Matsuno, T. Kawabata, K. Matsuda, S. Kamado, Y. Kojima and S. Ikeno: "HRTEM observation of the age hardening precipitation Mg-15wt\%Gd-Zr alloy”, Adv. Mater. Res., 15-17 (2007), 445-448.

39） T. Kawabata, Y. Fukuda, K. Matsuda, S. Kamado, Y. Kojima and S. Ikeno: "HRTEM Observation of Age Hardening Precipitates in $\mathrm{Mg}-$ 8.3\%Gd-3.7\% Y-0.76\%Zr Alloy”, Mater. Trans., 48 ( 2007), 954959.

40) T. Kawabata, T. Matsuno, K. Matsuda, S. Kamado, Y. Kojima and S. Ikeno: "HRTEM Observation of Precipitates at Early Stage of Aging in Mg-Gd-Zr Alloy", Mater. Sci. Forum, 561-565 (2007), 303-306.

41) K. Yamada, Y. Okubo, M. Shiono, H. Watanabe, S. Kamado and Y. Kojima: "Alloy development of High toughness $\mathrm{Mg}-\mathrm{Gd}-\mathrm{Y}-\mathrm{Zn}-\mathrm{Zr}$ alloys", Mater. Trans., 47 (2006), 1066-1070.

42) K. Yamada, Y. Okubo, S. Kamado and Y. Kojima: "Precipitate Microstructures of High Strength Mg-Gd-Y-Zn-Zr Alloys", Adv. Mater. Res., 11-12 (2006), 417-420.

43) T. Honma, T. Ohkubo, S. Kamado and K. Hono: "Effect of $\mathrm{Zn}$ additions on the age hardening of $\mathrm{Mg}-2.0 \mathrm{Gd}-1.2 \mathrm{Y}-0.2 \mathrm{Zr}$ alloys", Acta Mater., 55 (2007), 4137-4150.

44）黑木康徳, 尾崎智道, 田中 徹, 川端健詞, 塩野雅史, 鎌土 重晴, 小島 陽, 安倍 睦, 加藤武志: “ $M g-G d-Y-Z n$ 系高強 度鋳造用合金の強度特性”, 日本学術振興会耐熱金属材料 123 委員会研究報告，45（2004）特別号，235-243.

45） T. Ozaki, Y. Kuroki, K. Yamada, H. Hoshikawa, S. Kamado and Y. 
Kojima: "Mechanical properties of newly developed age hardenable Mg-3.2mol $\%$ Gd- $0.5 \mathrm{~mol} \% \mathrm{Zn}$ casting alloy", Mater Trans., 49 (2008), in press.

46）山田健太郎，星川裕聡，鎌土重晴，小島 陽：“Ag 添加した $M g-G d-Z n$ 系合金の析出挙動”, 軽金属学会第 113 回秋期大会 講演概要, (2007), 245-246.

47）星川裕聡，鎌土重晴，山田健太郎，小島 陽：“LPSO 型 $\mathrm{Mg}-\mathrm{Gd}-\mathrm{Cu}-\mathrm{Zn}-\mathrm{Zr}$ 系鋳造用合金のミクロ組織と機械的性質”, 軽金属学会第 113 回秋期大会講演概要，(2007)，399-400.

48) G. S. Cole: "Issues that Influence Magnesium's Use in the Automotive Industry", Mater. Sci. Forum, 419-422 (2003), 43-50.

49) S. Schumann and H. Friedrich: "Current and Future Use of Magnesium in the Automobile Industry", Mater. Sci. Forum, 419-422 (2003), 51-56.

50) T. Kaneko and M. Suzuki: "Automotive Applications of Magnesium Alloys", Mater. Sci. Forum, 419-422 (2003), 67-72.

51) W. E. Mercer: "Die Cast Alloys for Elevated Temperature Applications", SAE Technical Paper No. 900788, Detroit, SAE, (1990).

52）鎌土重晴，小島 陽：“自動車向けダイカスト用耐熱マグネシ ウム合金の開発”，工業材料，第 50 巻 8 号，(2002）, 日刊工業 新聞社, $26-30$

53）小島 陽，鎌土重晴：“マグネシウム合金の材料特性と開発動 向”，自動車技術，第 56 巻 10 号，(2002），自動車技術会，2127.

54) A. A. Luo: "Recent Magnesium Alloy Development for Automotive Powertrain Applications", Mater. Sci. Forum, 419-422 (2003), 5766.

55) H. Westengen and P. Bakke: "Magnesium Die Casting Alloys for Use in Applications Exposed to Elevated Temperatures: Can They Compete with Aluminium?”, Mater. Sci. Forum, 419-422 ( 2003), $35-40$.

56) E. Aghion, B. Bronfin, D. Eliezer, F. Von Buch, S. Schumann and H. Friedrich: "The Art of Developing New Magnesium Alloys for High Temperature Applications", Mater. Sci. Forum, 419-422 ( 2003), 407-418.

57) M. S. Yoo, Y. C. Kim, S. Ahn and N. J. Kim: "Tensile and Creep Properties of Squeeze Cast Mg Alloys with Various Second Phases", Mater. Sci. Forum, 419-422 (2003), 419-424.

58) G. Yuan, M. Liu, W. Ding, A. Inoue: "Development of a Cheep Creep Resistant Mg-Al-Zn-Si-base Alloy”, Mater. Sci. Forum, 419-422 (2003), 425-432.

59) T. Tsukeda, R. Uchida, M. Suzuki, J. Koike and K. Maruyama: "Newly Developed Heat Resistant Magnesium Alloy by Thixomolding", Mater. Sci. Forum, 419-422 (2003), 439-444.

60) A. A. Luo: "Materials comparison and potential applications of magnesium in automobiles", Magnesium Technology 2000, The Minerals, Metals \& Materials Society (TMS), Warrendale, Pennsylvania, (2000), 89-98.

61) M. O. Pekguleryuz and J. Renaud: "Creep resistance in $\mathrm{Mg}-\mathrm{Al}-\mathrm{Ca}$ casting alloys" Magnesium Technology 2000, The Minerals, Metals \& Materials Society (TMS), Warrendale, Pennsylvania, (2000), 279284

62) I. A. Anyanwu, S. Kamado, T. Honda, Y. Kojima, S. Takeda and T. Ishida: "Heat resistance of $\mathrm{Mg}-\mathrm{Zn}-\mathrm{Al}-\mathrm{Ca}$ alloy castings", Mater. Sci. Forum, 350-351 (2000), 73-78.

63) I. A. Anyanwu, T. Honda, S. Kamado, Y. Kojima, S. Takeda and T. Ishida: "Heat and Corrosion resistance of $\mathrm{Mg}-\mathrm{Zn}-\mathrm{Al}-\mathrm{Ca}$ alloys", Magnesium Alloys and Their Applications (Proc. of Intern. Cong. on Magnesium Alloys and Their Applications), Wiley-VCH, (2000), $110-115$.

64) S. Kamado, I. A. Anyanwu, S. Nozawa, Y. Kojima, S. Takeda and T. Ishida: "Development of Heat Resistant Magnesium Alloys for Automotive Powertrain Parts", Proc. of the 4th Pac. Rim Int. Conf. on Advanced Mater. and Processing, (2001), 1175-1178.

65） I. Anyanwu, Y. Gokan, S. Nozawa, S. Kamado, Y. Kojima, S. Takeda and T. Ishida: "Heat Resistant Magnesium Alloys for Automotive Powertrain Applications", Mater. Sci. Forum, 419-422 (2003), 445450.
66) Y. Gokan, I. Anyanwu, S. Nozawa, S. Kamado, Y. Kojima, S. Takeda and T. Ishida: "Development of Heat Resistant $\mathrm{Mg}-\mathrm{Zn}-\mathrm{Al}-\mathrm{Ca}-\mathrm{RE}$ diecasting Alloys", Mater. Sci. Forum, 419-422 (2003), 451-456.

67) I. A. Anyanwu, Y. Gokan, S. Nozawa, A. Suzuki, S. Kamado, Y. Kojima, S. Takeda and T. Ishida: "Development of New Diecastable $\mathrm{Mg}-\mathrm{Zn}-\mathrm{Al}-\mathrm{Ca}-\mathrm{RE}$ Alloys for High Temperature Applications", Mater. Trans., 44 (2003), 562-570.

68) I. A. Anyanwu, Y. Gokan, S. Nozawa, A. Suzuki, S. Kamado, Y. Kojima, S. Takeda and T. Ishida: "Effect of substituting cerium-rich mischmetal with lanthanum on high temperature properties of diecast Mg-Zn-Al-Ca-RE alloys", Mater. Sci. \& Eng. A, A380 (2004), 93-99.

69) I. A. Anyanwu, A. Suzuki, S. Kamado and Y. Kojima: "Optimization of $\mathrm{Mg}-\mathrm{Zn}-\mathrm{Al}-\mathrm{Ca}-\mathrm{La}$ Alloys for the Improvement of Casting Properties and Creep Resistance”, Mater Sci Forum, 488-489 (2005), 805-809.

70) A. P. Druschitz, E. R. Showalter, J. B. McNeill and D. L. White: "Evaluation of structural and high-temperature magnesium alloys at room temperature", Magnesium Technology 2002, ed. by H. I. Kaplan, The Minerals, Metals \& Materials Society (TMS), (2002), $117-122$.

71) D. Argo, M. Pekguleryuz, P. Labelle, P. Vermette, R. Bouchard and M. Lefebvre: "Process parameters and diecasting of noranda's AJ52 high temperature Mg-Al-Sr alloy", Magnesium Technology 2002, ed. by H. I. Kaplan, The Minerals, Metals \& Materials Society (TMS), (2002), 87-93.

72） F. von Buch, S. Schumann, H. Friedrich, E. Aghion, B. Bronfin, B. L. Mordike, M. Bamberger and D. Eliezer: "New die-casting alloy MRI153 for power-train applications", Magnesium Technology 2002, ed. by H. I. Kaplan, The Minerals, Metals \& Materials Society (TMS), (2002), 61-67.

73) Y. Mori, Y. Terada and T. Sato: "Microstructure Stability and Creep Strength in a Die-Cast AX52 Magnesium Alloy", Mater. Trans., 46 (2005), 1749-1952.

74） B. R. Powell, V. Rezhets, M. P. Balogh and R. A. Waldo: "The relationship between microstructure and creep behavior in AE-42 magnesium die casting alloy", Magnesium Technology 2001, The Minerals, Metals \& Materials Society (TMS), (2001), 175-181.

75) I. P. Moreno, T. K. Nandy, J. W. Jones, J. E. Allison and T. M. Pollock: "Microstructural stability and creep of rare-earth containing magnesium alloys", Scripta Mater., 48 (2003), 1029-1034.

76) M. C. Flemings: Solidification Processing, McGraw Hill, USA, (1974), 257.

77）小池淳一, 宮村剛夫：“多結晶マグネシウム合金における塑性 変形の微視的機構”, 軽金属, 54 (2004), 460-464.

78） S. Kamado and Y. Kojima: "Development of Magnesium Alloys with High Performance”, Mater. Sci. Forum, 546-549 (2007), 55-64.

79）鎌土重晴：“マグネシウム合金開発の最新動勢と新しい合金設 計”，日本材料学会第 29 回材料講習会「マグネシウム合金の ポテンシャルを引出すための材料学 一マグネシウムの素材 特性と成形性はどこまで改善できるか?」テキスト，(2006)， $17-25$.

80）楊 続躍, 三浦博己, 酒井 拓：“AZ31 マグネシウム合金の 高温変形による動的微細粒組織の生成”，軽金属，52（2002）, 318-323.

81）楊 続躍, 三浦博己, 酒井 拓：“高温加工マグネシゥム合金 AZ31 の等時間焼なまし特性”，日本金属学会誌，68（2004）， 946-951.

82）Jie XING，䊍田裕司，楊 続踓，三浦博己，酒井 拓：“AZ31 マグネシゥム合金の降温中多軸鍛造による微細粒組織の生成”, 軽金属, 54 (2004), 527-531.

83) Y. Yoshida, K. Arai, S. Itoh, S. Kamado and Y. Kojima: "Realization of high strength and high ductility for AZ61 magnesium alloy by severe warm working", Sci. and Tech. of Adv. Mater., 6 (2005), 185194.

84） Y. Yoshida, K. Arai, S. Itoh, S. Kamado and Y. Kojima: "Superplastic Deformation of AZ61 Magnesium Alloy having Fine Grains", Mater. Trans., 45 (2004), 2537-2541.

85）近藤勝義，都筑律子，杜 文博，鎌十重晴：“反復式塑性加工 
と固相合成法を利用したマグネシウム合金の高機能化リサイ クル”, 日本金属学会報, 43 (2004), 275-280.

86） C. L. Mendis, K. Oh-ishi, Y. Kawamura, T. Honma, S. Kamado and K. Hono: "Mechanical properties and microstructures of extruded $\mathrm{Mg}-2.4 \mathrm{at} \% \mathrm{Zn}$ alloys containing $\mathrm{Ag}$ and $\mathrm{Ca}$, Magnesium Technology 2008, TMS, (2008), 275-277.

87）本間智之, 川村善明, 鎌土重晴, 小島 陽：“高強度・高延性 $\mathrm{Mg}-\mathrm{Zn}-\mathrm{Ca}(-\mathrm{Ag}-\mathrm{Zr})$ 系合金押出し材の動的析出による強化機 構”, 軽金属学会第 114 回春期大会講演概要，(2008), 165-166.

88）川村善明，本間智之，鎌土重晴，小島 陽，村井 勉，高橋 泰，花木 悟：“Mg-Zn-Mn 合金押出し材のミクロ組織と機械 的性質”, 軽金属学会第 113 回秋期大会講演概要, (2007), 249250.

89）鎌土重晴, 山本健介, 本間智之, 村井 勉, 高橋 泰, 花木 悟：“Mg-Al-Ca 系合金押出し材の組織と引張特性”, 第 58 回 塑性加工学会連合講演会講演論文集，(2007)，491-492.

90）本間智之, 山本健介, 川村善明, 鎌土重晴： “高温押出しし たマグネシウム合金の機械的性質に及ぼす $\mathrm{Al}, \mathrm{Ca}$ 添加の効果”, 軽金属学会第 113 回秋期大会講演概要，(2007), 295-296.

91）山本健介, 本間智之, 鎌土重晴, 小島 陽, 村井 勉, 高橋 泰, 花木 悟： “ $\mathrm{Mg}-\mathrm{Al}-\mathrm{Ca}$ 合金押出し材のミクロ組織之機械 的性質に及ぼす Mn 添加の影響”, 軽金属学会第 114 回春期大 会講演概要, (2008), 163-164.

92） T. T. Sasaki, K. Yamamoto, T. Honma, S. Kamado and K. Hono: "A high-strength $\mathrm{Mg}-\mathrm{Sn}-\mathrm{Zn}-\mathrm{Al}$ alloy extruded at low temperature", Scripta Mater., 59 (2008), 1111-1114.

93） R. S. Busk：マグネシウム製品設計，軽金属協会 マグネシウム
委員会, (1988), 268-270.

94）マグネシゥム協会編：マグネシゥム技術便覧，カロス出版， (2000), 155.

95) E. F. Emley: Principles of Magnesium Technology, Pergamon press, (1966), 180-181.

96）井上 誠, 岩井正雄, 鎌土重晴, 小島 陽, 井籐忠男, 菅間 光雄 : “マンガン添加による AZ91D マグネシウム合金製ダイカ ス卜塗装部品からのリサイクル材の性状变化”, 資源之素材, 115 (1999), 189-194.

97）井上 誠，岩井正雄，鎌土重晴，小島 陽，井藤忠男，菅間 光雄：“塗料除去後リサイクルした AZ91D マグネシウム合金の 耐食性抢よび引張特性”, 軽金属, 49 (1999), 277-281.

98) M. Inoue, M. Iwai, S. Kamado, Y. Kojima, T. Itoh and M. Sugama: "Recycling of Magnesium Alloy Die-Castings with Paint Finishing", Trans. MRS-J, Mater. Res. Soc. of Japan, 24 (1999), 349-352.

99) T. B. Massalski: Binary Alloy Phase Diagrams Vol. 2, American Society for Metals, Ohio, ( 1986), 131-133.

100） アルミニウムの組織と性質, 軽金属学会, (2000), 217-230.

101) O. Lunder, K. Nisancioglu and T. Kr. Aune: "Corrosion of Cast Magnesium-Aluminum Alloys", Proc. Intern. Conf. on Recent Adv. in Sci. and Eng. of Light Metals, JILM, (1991), 157-168.

102) K. Nisancioglu, O. Lunder and T. Kr. Aune: "Corrosion Mechanism of AZ91 Magnesium Alloy", Proc. of 47th Annual World Magnesium Conf., Intern. Magnesium Association, Cannes, France, (1990), 43-50

103) O. Lunder, J. H. Nordlien and K. Nisancioglu: "Corrosion resistance of cast Mg-Al alloys", Corrosion Reviews, 15 (1997), 439-469. 